\title{
Current status and future perspective of radiopharmaceuticals in China
}

\author{
Ji Hu${ }^{1} \cdot$ Hongyu $\mathrm{Li}^{1} \cdot$ Yanying Sui ${ }^{1} \cdot \operatorname{Jin} \mathrm{Du}^{1,2}$ (1)
}

Received: 4 September 2021 / Accepted: 2 November 2021 / Published online: 12 November 2021

(c) The Author(s), under exclusive licence to Springer-Verlag GmbH Germany, part of Springer Nature 2021

\begin{abstract}
Radiopharmaceuticals are essential components of nuclear medicine and serve as one of the cornerstones of molecular imaging and precision medicine. They provide new means and approaches for early diagnosis and treatment of diseases. After decades of development and hard efforts, a relatively matured radiopharmaceutical production and management system has been established in China with high-quality facilities. This review provides an overview of the current status of radiopharmaceuticals on production and distribution, clinical application, and regulatory supervision and also describes some important advances in research and development and clinical translation of radiopharmaceuticals in the past 10 years. Moreover, some prospects of research and development of radiopharmaceuticals in the near future are discussed.
\end{abstract}

Keywords Radiopharmaceuticals · Current status · Radionuclides $\cdot$ Theranostic $\cdot$ Future perspective

\section{Introduction}

The research and production of medical radioisotopes and radiopharmaceuticals in China began in the 1950s [1]. In 1958, the first heavy water reactor and the first accelerator were built and put into use in China at the China Institute of Atomic Energy (CIAE). The first batch of 33 radioisotopes including ${ }^{24} \mathrm{Na},{ }^{32} \mathrm{P},{ }^{60} \mathrm{Co}$, and ${ }^{131} \mathrm{I}$ were successfully developed, thus initiating the undertakings of the production and application of radioisotopes and radiopharmaceuticals in China. Since the late 1950 s, ${ }^{131}$ I has been widely used in the diagnosis of thyroid function and radionuclide therapy for hyperthyroidism and thyroid cancer, and ${ }^{32} \mathrm{P}$ has been applied for the treatment of polycythemia vera and the control of cancerous pleural effusion and ascites, which

This manuscript is submitting to the China special issue

This article is part of the Topical Collection on Radiopharmacy

Jin Du

dujin@circ.com.cn

1 HighTech Atom Co., Ltd., No. 1 Sanqiang Road, Xinzhen, Fangshan District, Beijing 102413, China

2 China Isotope \& Radiation Corporation, No. 66 Changwa Zhongjie, Haidian District, Beijing 100089, China pioneered the application of radioisotopes in clinical diagnosis and treatment in China.

Since the 1970s, China has committed to the development of the technologies on production of key medical radioisotopes such as ${ }^{131} \mathrm{I},{ }^{125} \mathrm{I},{ }^{32} \mathrm{P},{ }^{99} \mathrm{Mo}$, and ${ }^{99 \mathrm{~m}} \mathrm{Tc}$. For example, two types of ${ }^{99} \mathrm{Mo} /{ }^{99 \mathrm{~m}} \mathrm{Tc}$ generators (fission and gel) were successively developed with stable manufacturing technique and established good manufacturing practice (GMP) facilities to meet the domestic market demand to a certain extent $[2,3]$. Currently, there are five nuclear reactors in service in China for research purposes, and their associated facilities have been used for the production of medical radioisotopes such as ${ }^{99} \mathrm{Mo},{ }^{125} \mathrm{I},{ }^{131} \mathrm{I},{ }^{32} \mathrm{P},{ }^{177} \mathrm{Lu},{ }^{89} \mathrm{Sr}$, and ${ }^{153} \mathrm{Sm}$. Among above five reactors, two of them are located in Beijing, and the other three are located in the Southwest China. However, because of various factors, only a small amount of ${ }^{131}$ I has been produced since 2008 , and the supply of other reactor-produced medical radioisotopes has heavily relied on importing abroad. As a comparison, accelerator-produced radioisotopes have been largely developed in China. As of 2020, three $30 \mathrm{MeV}$ cyclotrons and more than 120 small medical cyclotrons have been installed for the production of radionuclides such as ${ }^{18} \mathrm{~F},{ }^{123} \mathrm{I}$, and ${ }^{64} \mathrm{Cu}$.

The great progress on research and development of radiopharmaceuticals in China has been made during the course of more than half a century of growth [4]. Until now, over 40 radiopharmaceuticals involving 12 types of radionuclides 
including ${ }^{99 \mathrm{~m}} \mathrm{Tc},{ }^{18} \mathrm{~F},{ }^{131} \mathrm{I},{ }^{125} \mathrm{I},{ }^{153} \mathrm{Sm}$, and ${ }^{32} \mathrm{P}$ have been approved for commercial use by the National Medical Products Administration (NMPA). Out of the nearly 40 approved radiopharmaceuticals, 23 of them are ${ }^{99 \mathrm{~m}} \mathrm{Tc}$-labeled radiopharmaceuticals and associated kits, 1 is ${ }^{18} \mathrm{~F}$-fluorodeoxyglucose $\left(\left[{ }^{18} \mathrm{~F}\right] \mathrm{FDG}\right)$, and 9 of them are therapeutic radiopharmaceuticals such as $\left[{ }^{131} \mathrm{I}\right] \mathrm{NaI}$ oral solution (and/or capsules), $\left[{ }^{89} \mathrm{Sr}\right] \mathrm{SrCl}_{2}$ injection, and ${ }^{125} \mathrm{I}$ brachytherapy source which in contrast to other countries are regulatory categorized as radiopharmaceuticals in China.

At present, academic groups and associations that are engaged in the field of medical radioisotopes and radiopharmaceuticals in China mainly include the Chinese Isotope Society (CIS), the Chinese Nuclear and Radiochemistry Society (CNRS), the Chinese Society of Nuclear Medicine (CSNM), the China Isotope and Radiation Association (CIRA), and the Chinese Society of Radiopharmaceutical Science (CSRS). They have played a significant role in promoting the research, development, production, and clinical application of radiopharmaceuticals in China.

It should be noted that over the past few decades, a number of research institutes and universities in China have played an important role in conducting fundamental research, striving for technological progress as well as training talents and personnel in the fields of radiopharmaceuticals. These institutions include (in no particular order): (1) China Institute of Atomic Energy (Beijing); (2) Beijing Normal University (Beijing); (3) Chinese Academy of Medical Sciences (Beijing); (4) Shanghai Institute of Applied Physics (Chinese Academy of Sciences) (Shanghai); (5) Institute of High Energy Physics (Chinese Academy of Sciences) (Beijing); (6) China Academy of Engineering Physics (Sichuan Province); (7) Jiangsu Institute of Nuclear Medicine (Jiangsu Province); (8) Peking University (Beijing); (9) Fudan University (Shanghai); (10) Sichuan University (Sichuan Province); (11) Suzhou University (Jiangsu Province); and (12) Xiamen University (Fujian Province).

In June 2021, eight state departments including the China Atomic Energy Authority, the Ministry of Science and Technology, and the National Medical Products Administration jointly issued the Mid-and Long-term Development Plan (2021-2035) for Medical Isotopes. The Plan has deployed key tasks for the development of medical isotope-related industries including radiopharmaceuticals. It aims to advance the research and development of new radiopharmaceuticals, accelerate the realization of independent production and supply of medical isotopes, and promote the clinical application of radiopharmaceuticals. The Plan is of great significance and provides a roadmap in driving forward the development of radiopharmaceutical industry in China.

This review mainly focuses on the topic of the production and distribution, clinical application, regulatory supervision, research and development, and clinical translation of radiopharmaceuticals in China in the past 10 years, and it also discusses prospect of research and development on radiopharmaceuticals in China.

\section{Production and distribution of radiopharmaceuticals}

After decades of development, radiopharmaceutical industry in China has made great progress; the whole industry chain integrating research, production, sales, and application has been established; and the market scale has continued to grow [5]. At present, the companies engaged in production and sales of radiopharmaceuticals in China mainly include China Isotope \& Radiation Corporation and its subsidiaries HighTech Atom Co., Ltd. (HTA) and Chengdu Gaotong Isotope Co., Ltd. (Chengdu Gaotong), Dongcheng Pharmaceutical Group Co., Ltd. and its subsidiary Dongcheng AMS Pharmaceutical, Jiangyuan Pharmaceutical Factory of Jiangsu Institute of Nuclear Medicine, and Beijing Shihong Pharmaceutical Co., Ltd. of Beijing Normal University. The radiopharmaceuticals commercially available in China are summarized in the Table 1. It indicates that only a limited number of radionuclides and radiopharmaceuticals are currently produced and supplied in China, and the demand of clinical nuclear medicine is not fully met yet.

Because of the short half-life of ${ }^{99 \mathrm{~m}} \mathrm{Tc}(6.0 \mathrm{~h})$ and ${ }^{18} \mathrm{~F}$ (109.7 min), medical institutions can prepare such radiopharmaceuticals on their own for nuclear medicine clinical application. A more common option is to rely on commercial radiopharmaceutical production centers (also known as centralized radiopharmacy) that meet GMP standards for instant radiolabeling, production and distribution. To date, there are around 50 centralized radiopharmacies built by large radiopharmaceutical companies such as HTA and Dongcheng AMS Pharmaceutical that are running in the large- and medium-sized cities in China for production and distribution of ${ }^{99 \mathrm{~m}} \mathrm{Tc}$-labeled radiopharmaceuticals and positron radiopharmaceuticals including $\left[{ }^{18} \mathrm{~F}\right] \mathrm{FDG}$ (refer to Fig. 1). In addition to these commercial centralized radiopharmacies, large medical institutions equipped with cyclotrons independently produce $\left[{ }^{18} \mathrm{~F}\right] \mathrm{FDG}$ and other ${ }^{11} \mathrm{C}$-, ${ }^{15} \mathrm{~N}$-, and ${ }^{18} \mathrm{~F}$-labeled positron radiopharmaceuticals for clinical research in accordance with the requirements of Regulations on the Preparation of Positron Radiopharmaceuticals in Medical Institutions issued by the NMPA. As the nuclear medicine industry in China continues to grow, more centralized radiopharmacies need to be built to achieve extensive coverage and meet the pace of nuclear medicine development. It is estimated that by 2025 , about 50 new centralized radiopharmacies will be built across the country, and the availability and accessibility of radiopharmaceuticals will be significantly improved by then. 
Table 1 Radiopharmaceuticals commercially available in China

\begin{tabular}{|c|c|c|}
\hline Radionuclide & Radiopharmaceuticals & Main suppliers \\
\hline \multirow[t]{5}{*}{${ }^{131} \mathrm{I}$} & Sodium iodide $\left[{ }^{131} \mathrm{I}\right]$ oral solution $\left(\left[{ }^{131} \mathrm{I}\right] \mathrm{NaI}\right)$ & $\begin{array}{l}\text { HTA; Chengdu Gaotong; Department of Nuclear Physics and } \\
\text { Chemistry, China Academy of Engineering Physics }\end{array}$ \\
\hline & Sodium iodide $\left[{ }^{131} \mathrm{I}\right]$ capsules for diagnostic use $\left(\left[{ }^{131} \mathrm{I}\right] \mathrm{NaI}\right)$ & HTA \\
\hline & Sodium iodide $\left[{ }^{131} \mathrm{I}\right]$ capsules for therapeutic use $\left(\left[{ }^{131} \mathrm{I}\right] \mathrm{NaI}\right)$ & HTA \\
\hline & Sodium iodohippurate $\left[{ }^{131} \mathrm{I}\right]$ injection $\left(\left[{ }^{131} \mathrm{I}\right] \mathrm{OIH}\right)$ & Chengdu Gaotong \\
\hline & Iodine $\left[{ }^{131} \mathrm{I}\right]$ metuximab injection $\left(\left[{ }^{131} \mathrm{I}\right] \mathrm{I}\right.$-metuximab) & Chengdu Huasun Biotechnology \\
\hline${ }^{125} \mathrm{I}$ & Iodine $\left[{ }^{125} \mathrm{I}\right]$ brachytherapy source & $\begin{array}{l}\text { HTA; Seeds Biological Pharmacy (Tianjin); ZHIBO Bio- } \\
\text { Medical Technology (Beijing); Ningbo Junan Pharmaceuticals } \\
\text { Technology; etc }\end{array}$ \\
\hline${ }^{153} \mathrm{Sm}$ & Samarium $\left[{ }^{153} \mathrm{Sm}\right]$ lexidronam injection $\left(\left[{ }^{153} \mathrm{Sm}\right] \mathrm{Sm}\right.$-EDTMP $)$ & HTA \\
\hline${ }^{18} \mathrm{~F}$ & {$\left[{ }^{18} \mathrm{~F}\right]$-Flurodeoxyglucose injection $\left(\left[{ }^{18} \mathrm{~F}\right] \mathrm{FDG}\right)$} & $\begin{array}{l}\text { HTA; Nanjing Jiangyuan AMS Positron Research and Develop- } \\
\text { ment; Jiangsu Huayi Technology; Shanghai Atom Kexing } \\
\text { Pharmaceuticals }\end{array}$ \\
\hline${ }^{32} \mathrm{P}$ & Sodium phosphate $\left[{ }^{32} \mathrm{P}\right]$ oral solution (mainly $\left[{ }^{32} \mathrm{P}\right] \mathrm{Na}_{2} \mathrm{HPO}_{4}$ ) & HTA \\
\hline \multirow[t]{12}{*}{${ }^{99 \mathrm{~m}} \mathrm{Tc}$} & Sodium pertechnetate $\left[{ }^{99 \mathrm{~m}} \mathrm{Tc}\right]$ injection $\left(\left[{ }^{99 \mathrm{~m}} \mathrm{Tc}\right] \mathrm{NaTcO}_{4}\right)$ & HTA; Chengdu Gaotong \\
\hline & Technetium $\left[{ }^{99 \mathrm{~m}} \mathrm{Tc}\right]$ bicisate injection $\left(\left[{ }^{99 \mathrm{~m}} \mathrm{Tc}\right] \mathrm{Tc}-\mathrm{ECD}\right)$ & \multirow{11}{*}{$\begin{array}{l}\text { HTA; Chengdu Gaotong; Shanghai Atom Kexing Pharma- } \\
\text { ceuticals; Guangzhou HTA Pharmaceutical; Shanghai GMS } \\
\text { Pharmaceutical; Guangdong Ci Medicine }\end{array}$} \\
\hline & $\begin{array}{l}\text { Technetium }\left[{ }^{99 \mathrm{~m}} \mathrm{Tc}\right]-\mathrm{L}, \mathrm{L}-\mathrm{ethylenedicysteine} \mathrm{injection}\left(\left[{ }^{99 \mathrm{~m}} \mathrm{Tc}\right]\right. \\
\text { Tc-EC) }\end{array}$ & \\
\hline & Technetium $\left[{ }^{99 \mathrm{~m}} \mathrm{Tc}\right]$ sestamibi injection $\left(\left[{ }^{99 \mathrm{~m}} \mathrm{Tc}\right] \mathrm{Tc}-\mathrm{MIBI}\right)$ & \\
\hline & $\begin{array}{l}\text { Technetium }\left[{ }^{99 \mathrm{~m}} \mathrm{Tc}\right] \text { methylenediphosphonate injection }\left(\left[{ }^{99 \mathrm{~m}} \mathrm{Tc}\right]\right. \\
\text { Tc-MDP) }\end{array}$ & \\
\hline & Technetium $\left[{ }^{99 \mathrm{~m}} \mathrm{Tc}\right]$ etifenin injection $\left(\left[{ }^{99 \mathrm{~m}} \mathrm{Tc}\right] \mathrm{Tc}-\mathrm{EHIDA}\right)$ & \\
\hline & Technetium [ $\left.{ }^{99 \mathrm{~m}} \mathrm{Tc}\right]$ phytate injection $\left(\left[{ }^{99 \mathrm{~m}} \mathrm{Tc}\right] \mathrm{Tc}-\mathrm{Phytate}\right)$ & \\
\hline & Technetium $\left[{ }^{99 \mathrm{~m}} \mathrm{Tc}\right]$ pentetate injection $\left(\left[{ }^{99 \mathrm{~m}} \mathrm{Tc}\right] \mathrm{Tc}-\mathrm{DTPA}\right)$ & \\
\hline & $\begin{array}{l}\text { Technetium }\left[{ }^{99 \mathrm{~m}} \mathrm{Tc}\right] \text { albumin aggregated injection }\left(\left[{ }^{99 \mathrm{~m}} \mathrm{Tc}\right]\right. \\
\text { Tc-MAA) }\end{array}$ & \\
\hline & $\begin{array}{l}\text { Technetium }\left[{ }^{99 \mathrm{~m}} \mathrm{Tc}\right] \text { dimercaptosuccinate injection }\left(\left[{ }^{99 \mathrm{~m}} \mathrm{Tc}\right]\right. \\
\text { Tc-DMSA) }\end{array}$ & \\
\hline & Technetium $\left[{ }^{99 \mathrm{~m}} \mathrm{Tc}\right]$ tetrofosmin injection $\left(\left[{ }^{99 \mathrm{~m}} \mathrm{Tc}\right] \mathrm{Tc}-\mathrm{TF}\right)$ & \\
\hline & Technetium $\left[{ }^{99 \mathrm{~m}} \mathrm{Tc}\right]$ pyrophosphate injection $\left(\left[{ }^{99 \mathrm{~m}} \mathrm{Tc}\right] \mathrm{Tc}-\mathrm{PYP}\right)$ & \\
\hline${ }^{99} \mathrm{Tc}$ & $\begin{array}{l}\text { Technetium }\left[{ }^{99} \mathrm{Tc}\right] \text { methylenediphosphonate injection }\left(\left[{ }^{99} \mathrm{Tc}\right]\right. \\
\text { Tc-MDP })\end{array}$ & Chengdu Yunke Pharmaceuticals \\
\hline${ }^{201} \mathrm{Tl}$ & Thallium $\left[{ }^{201} \mathrm{Tl}\right]$ chloride injection $\left(\left[{ }^{201} \mathrm{Tl}\right] \mathrm{TlCl}\right)$ & HTA \\
\hline${ }^{89} \mathrm{Sr}$ & Strontium $\left[{ }^{89} \mathrm{Sr}\right]$ chloride injection $\left(\left[{ }^{89} \mathrm{Sr}\right] \mathrm{SrCl}_{2}\right)$ & $\begin{array}{l}\text { Chengdu Gaotong; Ningbo Junan Pharmaceuticals Technology; } \\
\text { Shanghai Atom Kexing Pharmaceuticals }\end{array}$ \\
\hline${ }^{223} \mathrm{Ra}$ & Radium $\left[{ }^{223} \mathrm{Ra}\right]$ chloride injection $\left(\left[{ }^{223} \mathrm{Ra}\right] \mathrm{RaCl}_{2}\right)$ & Bayer AG \\
\hline
\end{tabular}

*Data from https://www.nmpa.gov.cn

In recent years, because of the successful application of targeted radiopharmaceuticals in the clinical diagnosis and treatment, the radiopharmaceuticals industry has gradually become the focus of attention among financial capitals and innovative pharmaceutical companies. Some traditional pharmaceutical companies, such as Dongcheng Pharmaceutical Co. Ltd., Sinotau Pharmaceuticals, and Hengrui Pharma, have begun to set foot in the radiopharmaceutical industry and started research, development, and production of radiopharmaceutical. This will further boost the development of the radiopharmaceutical industry in China.

\section{Clinical applications of radiopharmaceuticals}

In April 2020, the Chinese Society of Nuclear Medicine carried out a biennial national census on current status of nuclear medicine in China [6]. The number of nuclear imaging cameras and clinical nuclear medicine practices in China are illustrated in Fig. 2. The result highlights that as of December 2019, there are 1148 departments (sections) engaged in nuclear medicine practices, $770(67.1 \%)$ of 
Fig. 1 The production and distribution network of radiopharmaceuticals in China. Centralized radiopharmacy refers to the production center for the diagnostic radiopharmaceuticals with radionuclides having shorter half-life, such as ${ }^{99 \mathrm{~m}} \mathrm{Tc}$ and ${ }^{18} \mathrm{~F}$. Radiopharmaceutical production base refers to the factory for the production of medical radioisotopes and the production of diagnostic and therapeutic radiopharmaceuticals labeled with radionuclides having longer half-life

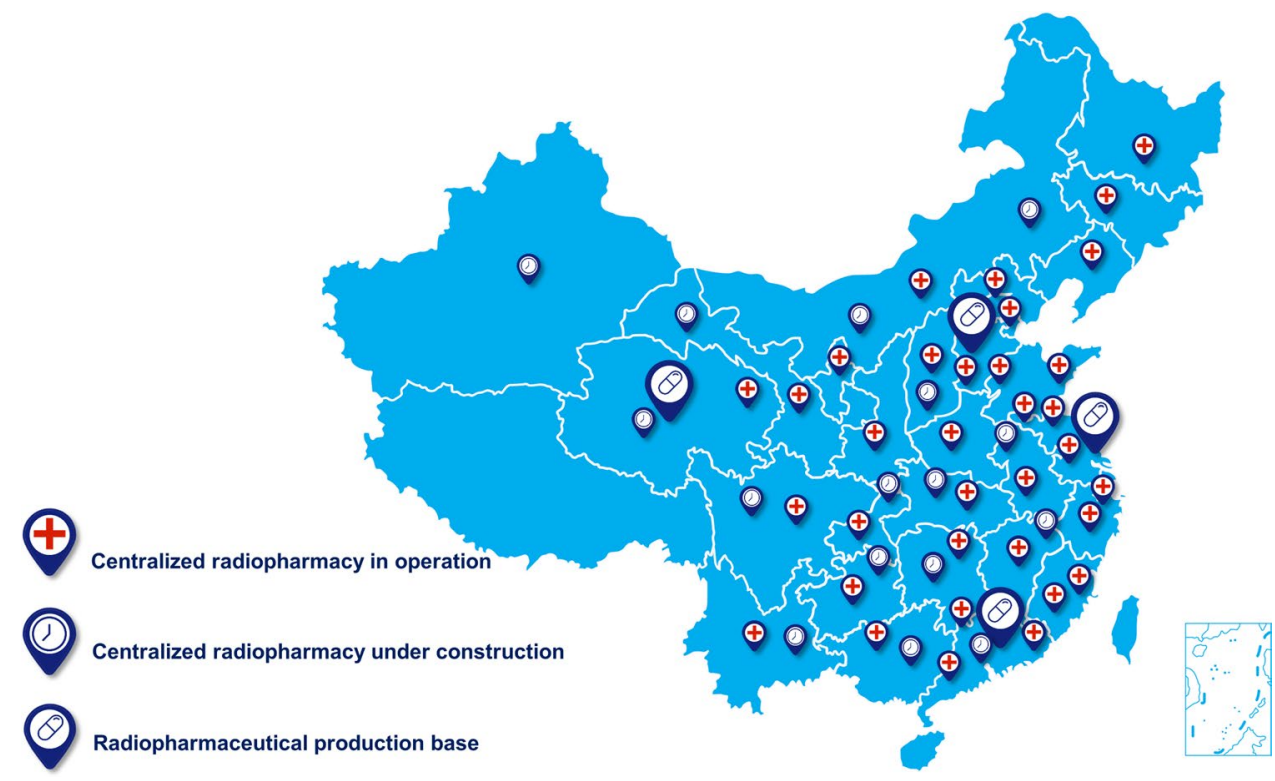

them have conducted radionuclide therapy. There are 427 sets of positron imaging equipment nationwide, including 23 sets of positron emission tomography-magnetic resonance imaging (PET-MRI) and 404 sets of PET-computerized tomography (CT). The number of single photon imaging equipment (including gamma camera, single photon emission computed tomography (SPECT), cardiac SPECT, SPECT-CT, and coincidence SPECT) amounts to 903 sets across the country. One hundred seventeen medical institutions are equipped with 120 medical cyclotrons for the preparation of $\left[{ }^{18} \mathrm{~F}\right]-\mathrm{FDG}$ and other positron radiopharmaceuticals.

In terms of PET/CT imaging, a total of 849,900 examinations were carried out in 2019 , of which $\left[{ }^{18} \mathrm{~F}\right] \mathrm{FDG}$ PET accounted for the majority: tumor imaging (94.5\%), central nervous system imaging (1.7\%), and cardiovascular system imaging $(0.6 \%)$. In addition, the total number of PET/MRI examinations was 14,095 in year 2019. With regard to the total number of SPECT examinations in year 2019, the figure stood at 2.51 million, up by $19.9 \%$ compared to that of 2017. SPECT mainly employs ${ }^{99 \mathrm{~m}} \mathrm{Tc}$-labeled radiopharmaceuticals. The top 5 SPECT examinations were skeletal system (account for $63.1 \%$ ) using [ $\left.{ }^{99 \mathrm{~m}} \mathrm{Tc}\right] \mathrm{Tc}-\mathrm{MDP}$, endocrine system $(15.9 \%)$ using $\left[{ }^{131} \mathrm{I}\right] \mathrm{NaI}$ and a few $\left[{ }^{99 \mathrm{~m}} \mathrm{Tc}\right] \mathrm{NaTcO}_{4}$, urinary system $(11.7 \%)$ using $\left[{ }^{99 \mathrm{~m}} \mathrm{Tc}\right] \mathrm{Tc}-\mathrm{DTPA}$, circulatory system (4.2\%) using [ [ $\left.{ }^{99 \mathrm{~m}} \mathrm{Tc}\right] \mathrm{Tc}-\mathrm{MIBI}$ and $\left[{ }^{99 \mathrm{~m}} \mathrm{Tc}\right] \mathrm{Tc}-\mathrm{TF}$, and digestive system (1.9\%) using [ ${ }^{99 \mathrm{~m}} \mathrm{Tc}$ ]Tc-EHIDA and [ ${ }^{99 \mathrm{~m}} \mathrm{Tc}$ ] Tc-Phytate.

At present, about $65 \%$ of the hospitals and/or medical institutions that use SPECT radiopharmaceuticals purchase ${ }^{99 \mathrm{~m}} \mathrm{Tc}$-labeled radiopharmaceuticals from the centralized radiopharmacies. Others purchase ${ }^{99} \mathrm{Mo} /{ }^{99 \mathrm{~m}} \mathrm{Tc}$ generators and ${ }^{99 \mathrm{~m}} \mathrm{Tc}$ cold kits to prepare ${ }^{99 \mathrm{~m}} \mathrm{Tc}$-labeled radiopharmaceuticals on their own. With regard to positron pharmaceuticals which is mainly $\left[{ }^{18} \mathrm{~F}\right] \mathrm{FDG}, 333$ hospitals and/or medical institutions purchase from radiopharmacies, while 119 hospitals and/or medical institutions prepare their own $\left[{ }^{18}\right.$ F]FDG. In addition, some medical institutions use their own cyclotrons to prepare positron radiopharmaceuticals such as $\left[{ }^{18} \mathrm{~F}\right] \mathrm{NaF},\left[{ }^{18} \mathrm{~F}\right] \mathrm{F}-\mathrm{PSMA}$ derivatives, $\left[{ }^{18} \mathrm{~F}\right]$ fluoromisonidazole ( $\left.\left[{ }^{18} \mathrm{~F}\right] \mathrm{FMISO}\right), 6-\left[{ }^{18} \mathrm{~F}\right]$ fluoro-L-3,4-dihydroxyphenylalanine $\left(\left[{ }^{18} \mathrm{~F}\right] \mathrm{F}-\mathrm{DOPA}\right),\left[{ }^{18} \mathrm{~F}\right]$ fluoro-ethyltyrosine $\left(\left[{ }^{18} \mathrm{~F}\right] \mathrm{FET}\right),\left[{ }^{18} \mathrm{~F}\right]$ fluorothymidine $\left(\left[{ }^{18} \mathrm{~F}\right] \mathrm{FLT}\right),\left[{ }^{13} \mathrm{~N}\right]$ $\mathrm{NH}_{3} \cdot \mathrm{H}_{2} \mathrm{O},\left[{ }^{15} \mathrm{O}\right] \mathrm{H}_{2} \mathrm{O},\left[{ }^{11} \mathrm{C}\right]$ Acetate, $\left[{ }^{11} \mathrm{C}\right]$ Methionine, $\left[{ }^{11} \mathrm{C}\right]$ Choline, $\left[{ }^{11} \mathrm{C}\right]$ flumazenil $\left(\left[{ }^{11} \mathrm{C}\right] \mathrm{FMZ}\right),\left[{ }^{11} \mathrm{C}\right]$ Raclopride,

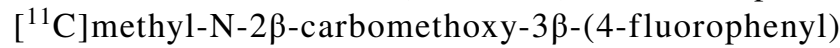
tropane $\left(\left[{ }^{11} \mathrm{C}\right] \mathrm{CFT}\right)$, and $\left[{ }^{11} \mathrm{C}\right]-\mathrm{N}$-methylspiperone $\left(\left[{ }^{11} \mathrm{C}\right]\right.$ NMSP) for the diagnosis and clinical research. Over the past few years, some medical institutions have also carried out research on the radiolabeling and clinical application of ${ }^{68} \mathrm{Ga}$-labeled positron radiopharmaceuticals such as $\left[{ }^{68} \mathrm{Ga}\right]$ Ga-DOTA-TATE, $\left[{ }^{68} \mathrm{Ga}\right] \mathrm{Ga}$-PSMA derivatives, and $\left[{ }^{68} \mathrm{Ga}\right]$ Ga-chemokine receptor $4\left(\left[{ }^{68} \mathrm{Ga}\right] \mathrm{Ga}-\mathrm{CXCR} 4\right)$ by purchasing ${ }^{68} \mathrm{Ge} /{ }^{68} \mathrm{Ga}$ generators imported from abroad.

Up to now, there are 2544 beds in total dedicated to radionuclide therapy in all the medical institutions that carry out radionuclide therapy across China. Nearly 530,000 treatments have been conducted annually, among which ${ }^{131} \mathrm{I}$ treatment of Graves' hyperthyroidism accounts for $27.6 \%$, and ${ }^{90} \mathrm{Sr} /{ }^{90} \mathrm{Y}$ applicator treatment for skin and eye diseases $25.5 \%,{ }^{99} \mathrm{Tc}$-methylene bisphosphonate treatment for rheumatoid arthritis $18.6 \%,{ }^{131}$ I treatment of differentiated thyroid cancer $15.9 \%,{ }^{32} \mathrm{P}$ application treatment $6.6 \%$, radioactive seed interstitial implantation treatment $2.4 \%$, and ${ }^{89} \mathrm{Sr}$ for bone metastasis $2.0 \%$. In recent years, some medical institutions have begun to use $\left[{ }^{223} \mathrm{Ra}\right] \mathrm{RaCl}_{2}$ for the treatment 
a

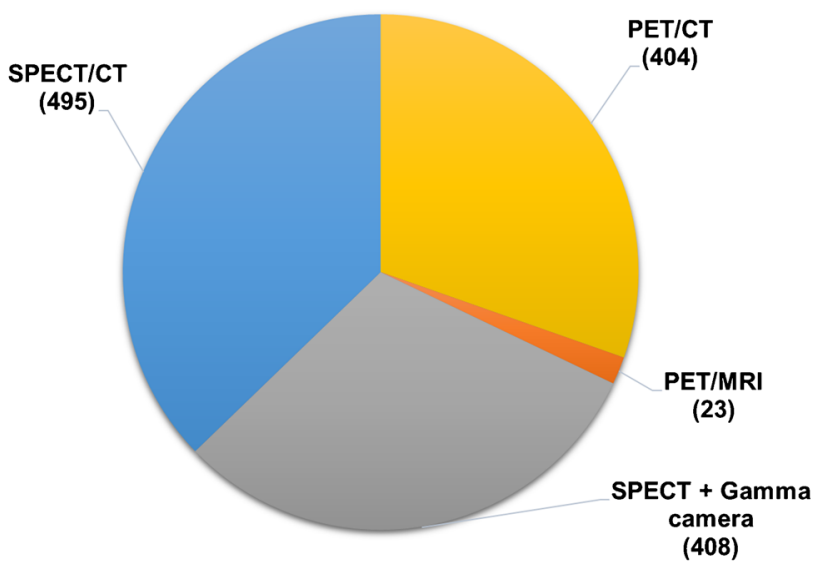

Nuclear imaging equipment

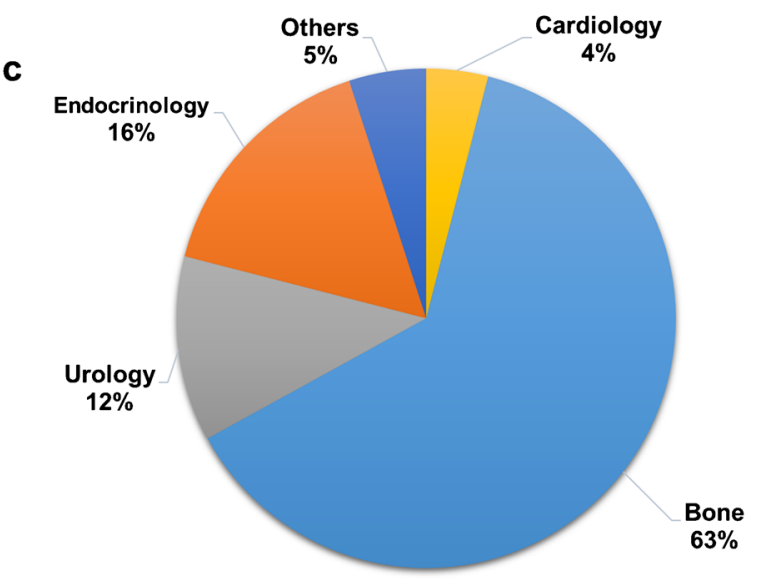

SPECT + SPECT/CT scans

Fig. 2 The number and type of nuclear imaging cameras (a), categories of top $3 \mathrm{PET} / \mathrm{CT}+\mathrm{PET} / \mathrm{MRI}$ studies performed in the year of 2019 (b), categories of top 5 single photon studies performed in the

of castrated prostate cancer patients with bone metastases, and some therapeutic radiopharmaceuticals such as $\left[{ }^{177} \mathrm{Lu}\right]$ Lu-DOTA-TATE, $\left[{ }^{177} \mathrm{Lu}\right] \mathrm{Lu}-\mathrm{DOTA}-\mathrm{TOC}$, and $\left[{ }^{177} \mathrm{Lu}\right] \mathrm{Lu}-$ PSMA have also been prepared and investigated for the clinical research of neuroendocrine tumors and prostate cancer.

\section{Radiopharmaceutical regulations and supervision}

Radiopharmaceutical administration in China has gone through a long process of continuous improvement. In the 1950s to 1960s [7], radiopharmaceuticals were regulated as medical radioisotopes. It was not until 1974 that radiopharmaceuticals began to be regulated as pharmaceuticals.

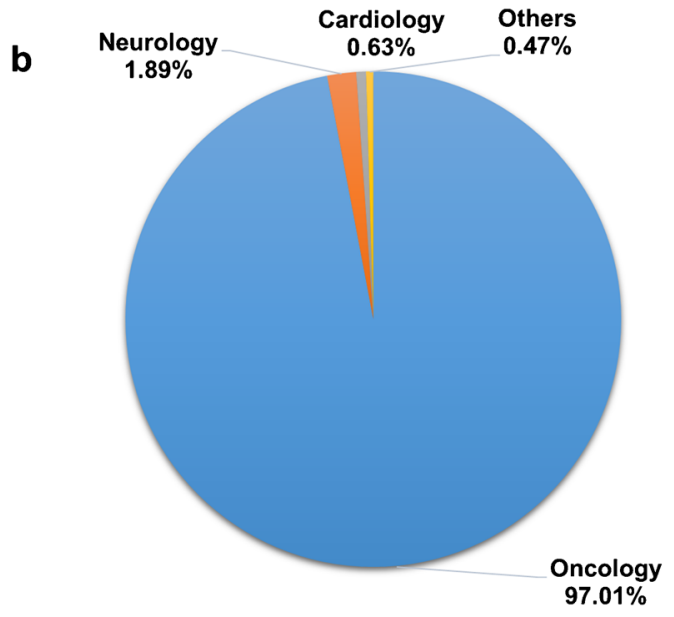

PET/CT + PET/MRI scans

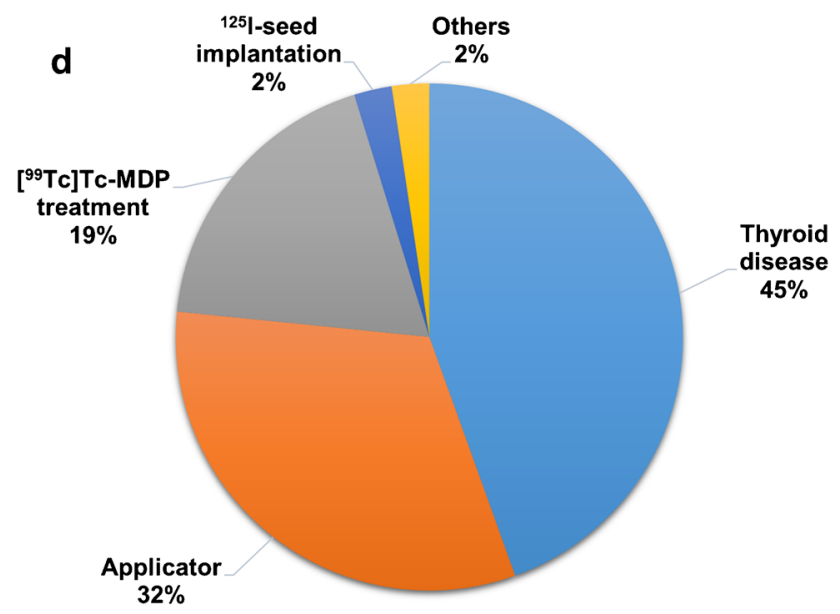

Radionuclide therapy

year of 2019 (c), categories of top 5 radionuclide therapy performed in the year of 2019 (d)

The 1977 edition of Chinese Pharmacopoeia included radiopharmaceuticals for the first time. In 1989, the State Council of China promulgated the Measures for the control of Radioactive Drugs, ushering in an era of lawbased administration of radiopharmaceuticals in China. In 2017, the Measures for the control of Radioactive Drugs was revised. The provisions on the development, clinical research and approval, production, operation, import and export, packaging and transportation, and use of radiopharmaceuticals were provided. A radiopharmaceutical production and handling enterprise must hold the "Radiopharmaceutical Production License" and/or the "Radiopharmaceutical Handling License". To be able to use radiopharmaceuticals, medical institutions must obtain a "Radiopharmaceutical Using License". 
Currently, the state authority responsible for the supervision and registration of radiopharmaceuticals is the NMPA and its directly affiliated units, comprising mainly of the Department of Drug Registration, the Center for Drug Evaluation (CDE), the National Institutes for Food and Drug Control, Center for Food and Drug Inspection (CFDI), and the Chinese Pharmacopoeia Commission (refer to Fig. 3).

Radiopharmaceutical-related policies and regulations that are currently in effect include The Drug Administration Law of the People's Republic of China (newly revised in 2019), Regulations for Implementation of the Drug Administration Law of the People's Republic of China (newly revised in 2019), Measures for the Control of Radioactive Drugs, and Good Manufacturing Practice for Pharmaceutical Products (amended in 2010).

In 2006, the NMPA promulgated the Regulations on the Administration of the Preparation of Positron Radiopharmaceuticals by Medical Institutions, which regulates in explicit terms on the licensing conditions for the use and preparation of radiopharmaceuticals in medical institutions. The licenses are classified into four levels: a class I or a higher level license should be held for the use of radioimmunoassay kits for in vitro diagnosis; a class II or a higher level license should be held for the use of radiopharmaceuticals; a class III or a higher level license should be held for the preparation of radiopharmaceuticals; and a class IV license should be held for the development and related clinical research of new-type of radiopharmaceuticals, meanwhile a filing application should be submitted to the NMPA.
The introduction and use of a new type of radiopharmaceuticals without marketing authorization in medical institutions are mainly through the pathway of investigator-initiated clinical studies. Investigators should submit the complete preclinical study data to the Clinical Research Management Committee and Ethics Committee for approval of a limited number of patient clinical studies which are not for the purpose of seeking marketing authorization. Furthermore, the preparation of relevant radiopharmaceuticals in medical institutions shall be carried out in accordance with good manufacturing practice for pharmaceutical products, and the radiopharmaceuticals prepared in medical institutions for clinical studies are for local in-house use only.

In light of the fact that radiopharmaceuticals are usually with short physical half-life, the NMPA has successively issued the related documents such as Guidelines for Technetium $\left[{ }^{99 m} T c\right]$ Radiopharmaceutical Quality Control and Guidelines for Positron Radiopharmaceutical Quality Control. In 2019, the newly revised Drug Administration Law of the People's Republic of China and Provisions of Drug Registration were issued, under which the marketing authorization holder (MAH) system was implemented. The regulation of clinical trials for new pharmaceuticals was reformed from the previous approval system into implied licensing. These revised regulations are also applicable to radiopharmaceuticals, presenting new opportunities to radiopharmaceutical innovation.

Since 2020, the NMPA has successively issued the Technical Guidelines for Clinical Evaluation of Diagnostic
Fig. 3 NMPA and its affiliated institutions responsible for the supervision and registration of radiopharmaceuticals in China

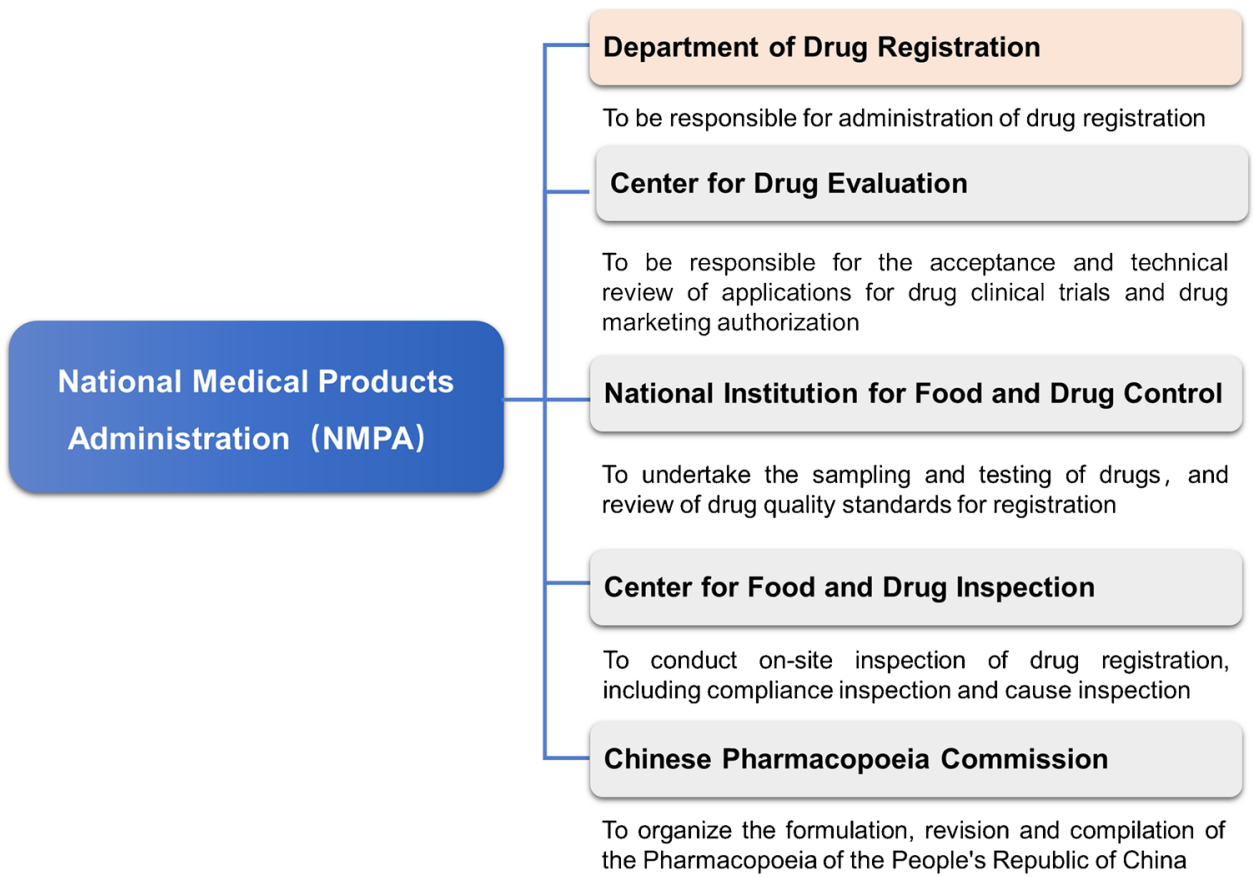


Radiopharmaceuticals and the Technical Guidelines for Non-clinical Research of Diagnostic Radiopharmaceuticals in order to promote and standardize the research, development, and clinical research of diagnostic radiopharmaceuticals in China.

\section{Important advances in research and development of radiopharmaceuticals}

\section{Production of medical radioisotopes}

In recent years, the preparation techniques of some major medical radioisotopes such as ${ }^{99} \mathrm{Mo}$ (LEU, low enriched uranium), ${ }^{177} \mathrm{Lu},{ }^{64} \mathrm{Cu},{ }^{123} \mathrm{I},{ }^{89} \mathrm{Zr}$, and ${ }^{211}$ At have been developed using reactors or cyclotrons, and some new progresses and breakthroughs have been achieved in China.

CIAE developed the production procedure of fission ${ }^{99}$ Mo with an emphasis on LEU target [8-10]. $\mathrm{UO}_{2}$ layer was electroplated on inner wall of a hollow stainless cylinder. After dissolution, radiochemical extraction, and further purification processes, the final ${ }^{99}$ Mo solution can meet the requirements for medical usage. CIAE also established the separation process of fission ${ }^{99} \mathrm{Mo}$ using $\mathrm{Al}_{2} \mathrm{O}_{3}$ chromatography. The recovery yield of ${ }^{99} \mathrm{Mo}$ was more than $90 \%$, and the decontamination effectiveness of the impurities such as $\mathrm{Ru}, \mathrm{Sr}, \mathrm{Zr}, \mathrm{Te}$, and Cs was more than $99.99 \%$, and more than $92 \%$ of ${ }^{131}$ I could be removed.

${ }^{177}$ Lu-labeled radiopharmaceuticals can be used in the treatment of primary and metastatic tumor and palliation of bone pain caused by metastases. In recent years, the continued improvement of ${ }^{177} \mathrm{Lu}$ preparation technology has further promoted the development of ${ }^{177} \mathrm{Lu}$ radiopharmaceuticals. Relying on China Mianyang Research Reactor (CMRR), China Academy of Engineering Physics has developed technology and production facilities for ${ }^{177} \mathrm{Lu}$, and it represents the first success in China to develop the production technology on no-carrier-added ${ }^{177} \mathrm{Lu}[11]$. Small batch production (curie level) was achieved, and the product has been used in clinical trials at some hospitals. In the meantime, Chengdu Gaotong has signed a technology licensing agreement with Isotopen Technologien München Group in Germany, and it will implement the development and GMP-grade production of no-carrier-added ${ }^{177} \mathrm{Lu}$ of up to one hundred curies scale in China.

${ }^{64} \mathrm{Cu}$ could form a perfect theranostic nuclide pair with ${ }^{67} \mathrm{Cu}$, and combining with its favorable properties makes ${ }^{64} \mathrm{Cu}$ a radioisotope of choice for clinical application of PET with unique advantages. Based on Cyclone-30 cyclotron and after a series of improvements on production process, HTA has established an automated process for ${ }^{64} \mathrm{Cu}$ production through ${ }^{64} \mathrm{Ni}(\mathrm{p}, \mathrm{n}){ }^{64} \mathrm{Cu}$ reaction with batch capacity greater than $74 \mathrm{GBq}$ and the radionuclide purity of the product greater than $99.9 \%[12,13]$, and the product has been provided to a number of research institutions.

Also based on Cyclone-30 cyclotron, using high abundance $(>99.8 \%){ }^{124} \mathrm{Xe}$ gas as target, HTA achieved the mass production of ${ }^{123} \mathrm{I}$ via ${ }^{124} \mathrm{Xe}(\mathrm{p}, 2 \mathrm{n}){ }^{123} \mathrm{Cs}\left(\beta^{+}\right)^{123} \mathrm{Xe}\left(\mathrm{EC}, \beta^{+}\right){ }^{123} \mathrm{I}$ reaction, and the batch activity could reach $111 \sim 148 \mathrm{GBq}$, and the irradiation yield was greater than $296 \mathrm{MBq} /(\mu \mathrm{A} \cdot \mathrm{h})$ [14]. ${ }^{123}$ I has been routinely produced and supplied by HTA domestically since 2017.

Based on CS-30 cyclotron, Sichuan University explored a simple and convenient method for radiochemical separation of ${ }^{89} \mathrm{Zr}$ with no harmful substance [15]. The radionuclidic purity of separated ${ }^{89} \mathrm{Zr}$ in the form of $\left[{ }^{89} \mathrm{Zr}\right] \mathrm{Zr}$-chloride was $99.99 \%$, and the recovery rate was $85 \% \pm 3 \%$. The yields of ${ }^{89} \mathrm{Zr}$ via the reaction of $(\mathrm{p}, \mathrm{n})$ or $(\mathrm{d}, 2 \mathrm{n})$ on $\mathrm{Y}$ target were also evaluated, and the latter one was proved to be more favorable for the production of ${ }^{89} \mathrm{Zr}$ with a yield of $58 \pm 4 \mathrm{MBq} / \mu \mathrm{A} \cdot \mathrm{h}$.

Sichuan University also conducted research on the preparation of alpha particle emitting radioisotope ${ }^{211} \mathrm{At}$ using CS30 cyclotron via ${ }^{209} \mathrm{Bi}(\alpha, 2 \mathrm{n}){ }^{211}$ At reaction [16]. Bismuth target was prepared by electroplating method. Using a homemade high-temperature dry distillation still, around $200 \mathrm{MBq}$ of ${ }^{211} \mathrm{At}$ was isolated, with the ratio of ${ }^{211} \mathrm{Po} /{ }^{211} \mathrm{At}$ less than $10^{-8}$.

\section{Research and development of radiopharmaceuticals}

Over the last decade, tremendous progress has been made in the development of novel radiopharmaceuticals by a large number of universities, hospitals, and research institutions in China. Numerous publications in this topic have become available in the literature, including a recent manuscript in Nature [17] and increasing number of publications in EJNMMI [18-24]. The trajectory has displayed a major upward trend over the last decade, which clearly showed that this is a highly vibrant field. A comprehensive summary of the progress in the development of novel radiopharmaceuticals in China over the last decade is far beyond the scope of this review article, and interested authors are referred to these excellent review articles for more details [4, 25]. Below, we will only briefly mention a few representative tracers and therapeutic radiopharmaceuticals for various applications in cancer and other diseases.

\section{Central nervous system imaging agents}

Potential radiotracers for $\beta$-amyloid plaque and Tau protein in Alzheimer's disease

Patients with Alzheimer's disease (AD) present with both extracellular amyloid- $\beta$ (A $\beta)$ plaques and intracellular tau-containing neurofibrillary tangles in the brain [26]. 
Therefore, $A \beta$ plaques and Tau protein are important pathological features of $\mathrm{AD}$, which are considered to be the important targets for early diagnosis of $\mathrm{AD}$.

Cui et al. reported the design and synthesis of a series of PET probes for $A \beta$ plaque imaging [27-32]. Among them, $\left[{ }^{18} \mathrm{~F}\right]$ Florbetazine, which has a new molecular structure of dihydrazone, demonstrates suitable pharmacokinetic properties including high initial brain uptake and fast brain clearance in rodents and non-human primates, and it also shows comparative affinity compared to the Food and Drug Administration (FDA) approved $\left[{ }^{18} \mathrm{~F}\right]$ Florbetapir and $\left[{ }^{18} \mathrm{~F}\right]$ Florbetaben [27]. Xu et al. reported a new $\mathrm{A} \beta$ plaque radiotracer $\left[{ }^{18}\right.$ F]DRKXH1 (5-(4-(6-(2-[18]fluoroethoxy)ethoxy) imidazo[1,2-alpha]pyridin-2-yl)phenyl), whose distribution volume ratios value is higher than that of $\left[{ }^{18} \mathrm{~F}\right]$ Florbetapir $(1.29 \pm 0.05$ vs. $1.05 \pm 0.08)$ [20]. The AD patients have high retention in cortical regions, while healthy control subjects have uniformly low radioactivity uptake.

A chiral 2-fluoromethyl-1,2-ethylenediol side chain was attached to the 2-phenylquinoxaline backbone to increase hydrophilicity of the compound, thereby improving the binding affinity and selectivity of the probe toward Tau tangles on $\beta$-amyloid plaques (A $\beta)$. Quantitative binding assays with $\mathrm{AD}$ homogenates show that the probes (R)-1-fluoro-3-(4(6-(methylamino)quinoxalin-2-yl)-phenoxy)propan-2-ol $((R)-5)$ and (S)-1-(4-(6-(dimethylamino)quinoxalin-2-yl) phenoxy)-3-fluoropropan-2-ol ((S)-16) have high affinity $\left(K_{\mathrm{i}}=4.1\right.$ and $10.3 \mathrm{nM}$, respectively) and high selectivity (30.5-fold and 34.6-fold, respectively) for Tau tangles [33]. In addition, they display sufficient blood-brain barrier penetration ( $7.06 \%$ and $10.95 \% \mathrm{ID} / \mathrm{g}$, respectively) and suitable brain kinetics $\left(\right.$ brain $_{2 \text { min }} /$ brain $_{60 \text { min }}=10.1,6.5$, respectively) in normal mice. These results demonstrate that $(R)-\left[{ }^{18} \mathrm{~F}\right] 5$ and $(S)-\left[{ }^{18} \mathrm{~F}\right] 16$ are promising PET probes for Tau tangles imaging.

\section{Potential radiotracers for imaging of sigma-1 receptor}

Sigma-1 $(\sigma 1)$ receptors are proved to be related to brain dysfunction and tumors as well as heart failure. Development of specific radiotracers for $\sigma 1$ receptor imaging may provide useful diagnostic tools for investigation of their pathophysiology [34].

Jia's group designed and synthesized a range of new ${ }^{18} \mathrm{~F}$-labeled compounds that show potential for imaging $\sigma 1$ receptor, including benzylpiperazine derivatives such as $1-\left(4-{ }^{18} \mathrm{~F}\right.$-fluorobenzyl)-4-((tetrahydrofuran-2-yl)methyl) piperazine [35], 4-phenylpiperidine-4-carbonitrile derivatives [36], 1,4-dioxa-8-azaspiro[4,5]decane derivatives [37], and 1-oxa-8-azaspiro[4.5]decane derivatives [38]. $\left[{ }^{18} \mathrm{~F}\right]$ FBFP was synthesized in one step from an iodonium ylide precursor, and it possesses higher regional non-displaceable binding potential (BPND) values across the brain regions compared with (S)- $\left[{ }^{18} \mathrm{~F}\right]$ fluspidine [39]. $\left[{ }^{18} \mathrm{~F}\right] \mathrm{FBFP}$ displays high brain uptake and suitable tissue kinetics for quantitative analysis in cynomolgus monkeys.

\section{Myocardial perfusion imaging agents}

Myocardial perfusion imaging is a well-established noninvasive method for diagnosing coronary artery disease.

Recently, Zhao et al. reported the optimization of biodistribution properties of radiotracers $\left[{ }^{99 \mathrm{~m}} \mathrm{Tc}\right] \mathrm{TcCl}(\mathrm{CDO})$ $\left.(\mathrm{CDOH})_{2} \mathrm{~B}-\mathrm{R}\right]\left(\mathrm{CDOH}_{2}=\right.$ cyclohexanedione dioxime $)$ using different boronate caps [40]. Among these 11 new ${ }^{99 \mathrm{~m}} \mathrm{Tc}$ labeled radiotracers, $\left[{ }^{99 \mathrm{~m}} \mathrm{Tc}\right] \mathrm{Tc}-3 \mathrm{SPboroxime}[\mathrm{R}=3 \mathrm{SP}$; 3-(methylsulfonyl)pyridine] shows the most promising characteristics as an optimal heart imaging agent. The SPECT image quality with [ $\left.{ }^{99 \mathrm{~m}} \mathrm{Tc}\right] \mathrm{Tc}-3 \mathrm{SPboroxime}$ in $\mathrm{SD}$ rats is better than that with $\left[{ }^{99 \mathrm{~m}} \mathrm{Tc}\right] \mathrm{Tc}$-teboroxime. High heart uptake and long myocardial retention of ${ }^{99 \mathrm{~m}} \mathrm{Tc}-3 \mathrm{SP}$ boroxime have been confirmed in swine models [41].

Zhang et al. reported three novel ${ }^{18} \mathrm{~F}$-labeled pyridaben analogues (Fmpp1, Fmpp2, and Fmpp3) for potential myocardial perfusion imaging [42]. In the whole-body PET/ CT images of mini-swine, $\left[{ }^{18} \mathrm{~F}\right] \mathrm{Fmpp} 2$ shows excellent initial heart standardized uptake value (SUV) (7.12 at $5 \mathrm{~min}$ p.i.) and good retention (5.75 at $120 \mathrm{~min}$ p.i.). The heart/ liver SUV ratios are 4.12, 5.42, and 5.99 at 30, 60, and $120 \mathrm{~min}$ after injection, respectively. The favorable biological properties of $\left[{ }^{18} \mathrm{~F}\right] \mathrm{Fmpp} 2$ suggest that it is worth further investigation.

\section{Tumor imaging agents}

\section{Prostate-specific membrane antigen targeting radiotracers}

Prostate-specific membrane antigen (PSMA) is overexpressed on the surface of the most of prostate cancer cells, and this expression of PSMA increases in low differentiated, metastatic, and androgen-independent prostate cancer cells. Therefore, PSMA is a promising target for diagnosis and therapy of prostate cancer [43].

In an effort to seek novel agents targeting PSMA, based on oxalyldiaminopropionic acid (ODAP), 16 ligands with structural modifications in PSMA S1' binding pocket were synthesized and evaluated for PSMA inhibition by Duan et al. (S)-3-(carboxyformamido)-2-(3-(carboxymethyl)ureido) propanoic acids prove to be potent PSMA ligands with $\mathrm{Ki}$ values ranging from 0.08 to $8.98 \mathrm{nM}$ [44]. Twelve ODAPurea-based ligands were synthesized and radiolabeled with ${ }^{68} \mathrm{Ga}$ [22]. [ $\left.{ }^{68} \mathrm{Ga}\right] \mathrm{Ga}-\mathrm{P} 137$ with the side chain of naphthalenyl can image PSMA in xenograft models and humans, with 
lower bladder accumulation to the Glu-Urea-based agent, $\left[{ }^{68} \mathrm{Ga}\right] \mathrm{Ga}-\mathrm{PSMA}-617$.

Liu et al. reported a novel PSMA inhibitor, 6-hydrazinonicotinate-amino-caproic acid-lysine-urea-glutamate (HYNIC-ALUG), which was labeled with ${ }^{99 \mathrm{~m}} \mathrm{Tc}$ [45]. Preliminary clinical results show that this probe can be used to guide surgical procedures to remove more metastatic lymph nodes, and it can be of great value for response assessment and prediction of the effectiveness of treatment in metastatic castration resistance prostate cancer (mCRPC) patients after long-term abiraterone treatment.

Based on the Glu-Ureido-Lys binding motif, three ${ }^{18} \mathrm{~F}$-labeled PSMA tracers with a more lipophilic quinoline functional spacer were designed, synthesized, evaluated, and compared with $\left[{ }^{18} \mathrm{~F}\right] \mathrm{DCFPyL}$ by Zhang et al. [46]. There is no significant correlation between the renal elimination and the lipophilicity of the tracers in all species. However, the more lipophilic of the tracer was, the more radioactivity accumulated in the liver of primate and human, and the fewer radioactivity was to be excreted to the bladder with urine. The screened tracer $\left[{ }^{18} \mathrm{~F}\right] 8 \mathrm{c}$, with a $K_{i}$ value of $4.58 \mathrm{nM}$, displays notable low bladder retention and demonstrates good imaging properties in patients with prostate cancer.

\section{Intergrin $\alpha_{v} \beta_{3}$ targeting radiotracers}

The integrin $\alpha_{\mathrm{v}} \beta_{3}$ is highly expressed in neovascular epithelium of various tumors, which is a highly potential target for tumor diagnosis and therapy, and tripeptide sequence of arginine-glycine-aspartic acid (RGD) is the specific ligand which can be combined to integrin $\alpha_{v} \beta_{3}$ [47].

Researchers in China have made great effort on the exploration of RGD peptides labeled with $\left[{ }^{18} \mathrm{~F}\right] \mathrm{AlF},{ }^{68} \mathrm{Ga}$, and ${ }^{99 \mathrm{~m}} \mathrm{Tc}$, such as $\left[{ }^{18} \mathrm{~F}\right] \mathrm{F}$-Alfatide injection [48], $\left[{ }^{68} \mathrm{Ga}\right]$ Ga-cycratide [49], $\left[{ }^{68} \mathrm{Ga}\right] \mathrm{Ga}-\mathrm{NOTA}-\mathrm{PEG} 3-\beta-\mathrm{Glu}-\mathrm{RGD}$ [50], [ $\left.{ }^{99 \mathrm{~m}} \mathrm{Tc}\right] \mathrm{Tc}-3$ PRGD2 [51], and [ $\left.{ }^{99 \mathrm{~m}} \mathrm{Tc}\right] \mathrm{Tc}-\mathrm{RWY}$ [52]. Among them, $\left[{ }^{18} \mathrm{~F}\right] \mathrm{F}$-Alfatide injection used for the diagnosis of tumor lymph metastasis is carrying out phase II study, and $\left[{ }^{99 \mathrm{~m}} \mathrm{Tc}\right] \mathrm{Tc}-3 \mathrm{PRGD} 2$ injection used for benign and malignant diagnosis of lung tumors and diagnosis of lymph node metastasis is in the phase III study.

\section{PD-1/PD-L1 targeting radiotracers}

In recent years, along with the clinical success of tumor immunotherapy, it is very important to screen the beneficiaries, predict the efficacy of drugs, and guide the clinical treatment during the immunotherapy. Accurate detection of PD-1/PD-L1 can be used to screen patients most likely to be responsive to PD-1/PD-L1 immunotherapy and to distinguish reactive tumors from refractory tumors at an early stage [53].
Using a single-domain antibody, NM-01, against PD-L1, radiolabeled site specifically with ${ }^{99 \mathrm{~m}} \mathrm{Tc}$ for SPECT, Xing et al. conducted early phase I study in non-small cell lung cancer, which demonstrates that ${ }^{99 \mathrm{~m}} \mathrm{Tc}$-labeled anti-PDL1-single-domain antibody SPECT/CT imaging is safe and associated with acceptable dosimetry [54]. Tumor uptake is readily visible against background tissues, particularly at $2 \mathrm{~h}$ when the primary tumor-to-blood-pool ratios (1.24 to 3.53 (mean, 2.22)) correlate with PD-L1 immunohistochemistry results $(r=0.68, P=0.014)$.

Miao et al. reported the radiosynthesis of the small molecule PD-L1 inhibitor $\left[{ }^{18} \mathrm{~F}\right] \mathrm{LN}$ via ${ }^{18} \mathrm{~F}-{ }^{19} \mathrm{~F}$ isotope exchange reaction [55]. $\left[{ }^{18} \mathrm{~F}\right] \mathrm{LN}$ was achieved with a high radiochemical purity above $95 \%$. PET reveals that $\left[{ }^{18} \mathrm{~F}\right] \mathrm{LN}$ enters into PD-L1 expressing tumor site and visualizes the outline of tumor. And tumor uptake reaches the maximum $(1.96 \pm 0.27 \% \mathrm{ID} / \mathrm{g})$ at $15 \mathrm{~min}$ in the positive group, 2.2 -fold higher than that of the negative or the blocked groups.

Huang et al. reported the construction of a novel heavy chain-only antibody named Nb6 with high affinity for hPDL1 [56]. $\left[{ }^{124} \mathrm{I}\right] \mathrm{I}-\mathrm{anti}-\mathrm{hPD}-\mathrm{L} 1 \mathrm{Nb6}$ and $\left[{ }^{64} \mathrm{Cu}\right] \mathrm{Cu}-\mathrm{NOTA}-\mathrm{Nb} 6$ were prepared respectively for PET to screen patients with malignant tumors such as osteosarcoma and lung adenocarcinoma [56, 57]. JS001 (toripalimab) is a humanized IgG monoclonal antibody which strongly inhibits PD1. Huang et al. tested the new immuno-PET probe $\left[{ }^{124} \mathrm{I}\right] \mathrm{I}-\mathrm{JS} 001$ to verify its potential in PD1-positive tumors patients [58]. Yang's group also conducted a first-in-human study of $\left[{ }^{68} \mathrm{Ga}\right] \mathrm{Ga}-\mathrm{NOTA}-\mathrm{WL} 12$ (a PD-L1-binding peptide radiotracer) demonstrating the safety and feasibility of the tracer for the detection of the tumor PD-L1 expression levels [59].

\section{${ }^{99 m}$ Tc-labeled glucose derivatives}

To seek novel ${ }^{99 \mathrm{~m}} \mathrm{Tc}$-labeled glucose derivatives as tumor imaging agents, Zhang's group reported the synthesis and evaluation of a series of ${ }^{99 \mathrm{~m}} \mathrm{Tc}$-labeled D-glucosamine derivatives with isonitrile as a coordinating group; among them, $\left[{ }^{99 \mathrm{~m}} \mathrm{Tc}\right] \mathrm{Tc}-\mathrm{CN} 7 \mathrm{DG}$ shows the highest tumor uptake and tumor-to-background ratios in the biodistribution and SPECT/CT studies in mice bearing A549 tumor xenografts [60]. $\left.{ }^{[9 \mathrm{~m}} \mathrm{Tc}\right] \mathrm{Tc}-\mathrm{CN} 5 \mathrm{DG}$ could be readily prepared by using a CN5DG kit (Fig. 4) and was further studied in U87MG, HCT-116, PANC-1, and TE-1 tumor xenografts mice models to verify its potential application for imaging of different kinds of tumors (Fig. 5) [61, 62]. The biodistribution data shows that the tumor/muscle ratios (from $4.08 \pm 0.42$ to $9.63 \pm 3.53$ ) and tumor/blood ratios (from $17.18 \pm 7.40$ to $53.17 \pm 16.16)$ of $\left[{ }^{99 \mathrm{~m}} \mathrm{Tc}\right] \mathrm{Tc}-\mathrm{CN} 5 \mathrm{DG}$ in four tumor models are high. These results demonstrate that $\left[{ }^{99 \mathrm{~m}} \mathrm{Tc}\right] \mathrm{Tc}-\mathrm{CN} 5 \mathrm{DG}$ may become a broad-spectrum SPECT probe for tumor imaging. Phase I clinical trial of this agent is in progress. 
Fig. 4 Preparation of $\left[{ }^{99 m} \mathrm{Tc}\right] \mathrm{Tc}-$ CN5DG and the chemical structure of CN5DG and [ $\left.{ }^{99 \mathrm{~m}} \mathrm{Tc}\right]$ Tc-CN5DG. Reproduced from Translational Oncology, Vol. 14/1, Zhang $X$ et al. [61, 62], Evaluation of ${ }^{99 \mathrm{~m}} \mathrm{Tc}-\mathrm{CN} 5 \mathrm{DG}$ as a broad-spectrum SPECT probe for tumor imaging, 100,966, Copyright (2021), with permission from Elsevier

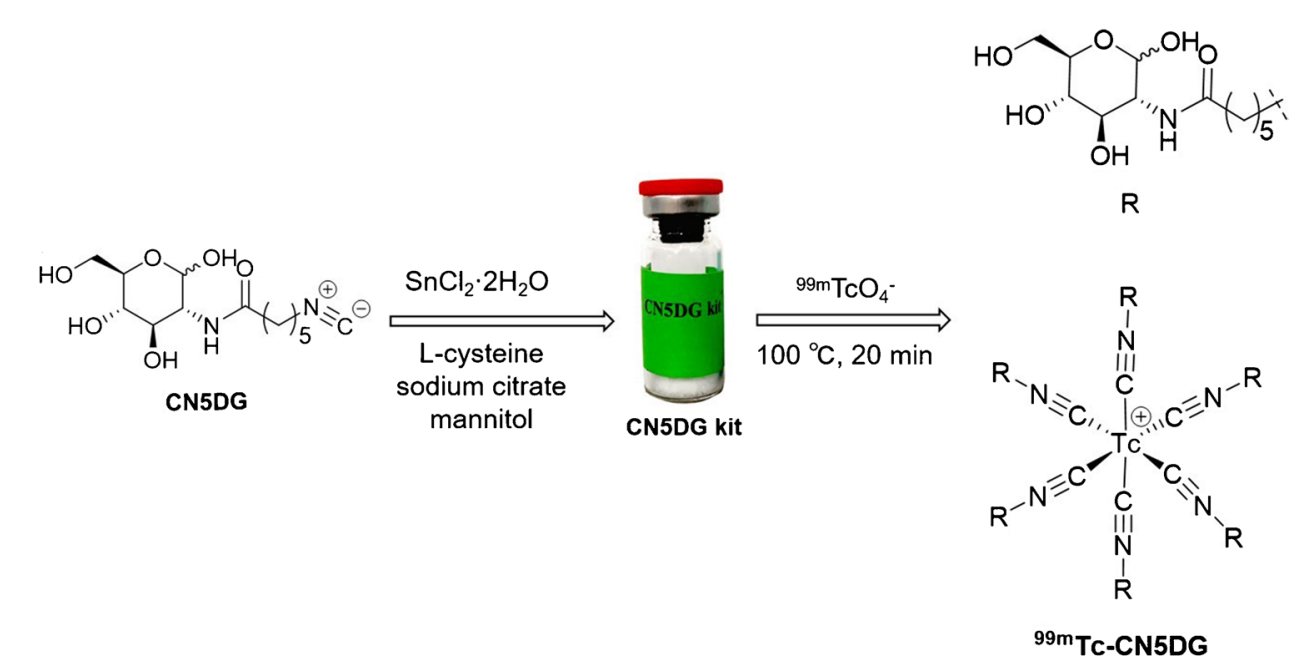

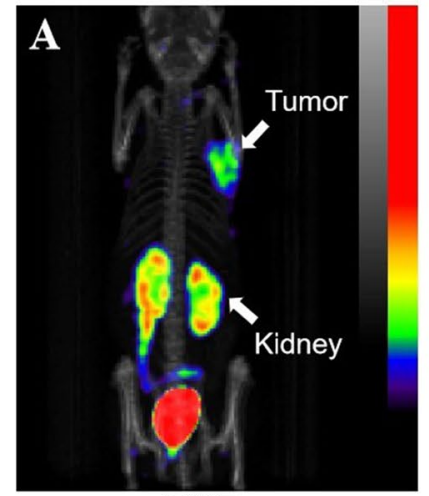

U87

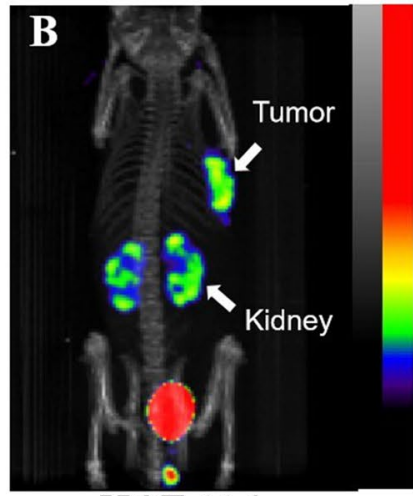

HCT-116

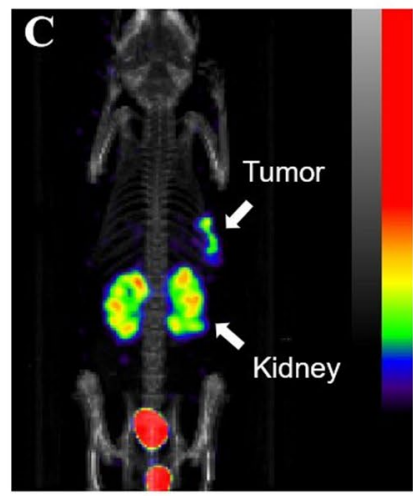

PANC-1

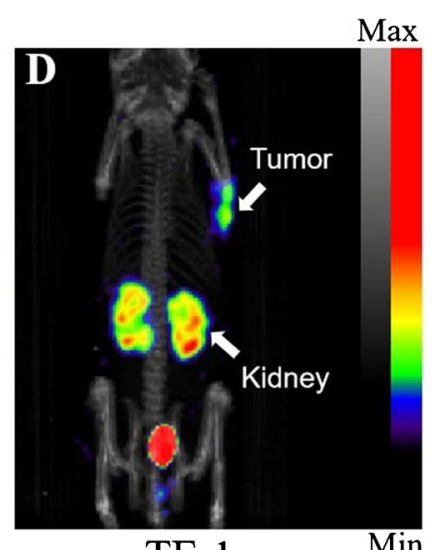

TE-1
Fig. 5 SPECT/CT images of $\left[{ }^{99 \mathrm{~m}} \mathrm{Tc}\right] \mathrm{Tc}-\mathrm{CN} 5 \mathrm{DG}$ in nude mice bearing U87 MG(A), HCT-116(B), PANC-1(C) and TE-1(D) tumor xenografts at $2 \mathrm{~h}$ after intravenous injection. Reproduced from Trans-

\section{Amino acids based radiotracers}

Liu's group developed ${ }^{18} \mathrm{~F}$-labeled boramino acid derivatives $\left[{ }^{18} \mathrm{~F}\right] \mathrm{Ala}-\mathrm{BF}_{3}$ and $\left[{ }^{18} \mathrm{~F}\right] \mathrm{Gln}-\mathrm{BF}_{3}$ for tumor imaging $[63,64]$. PET study demonstrates that these probes show remarkable and selective tumor uptake in BGC-823 and 4T1 xenografts, respectively. ${ }^{18} \mathrm{~F}$-trifluorobborate-derived tyrosine (denoted as $\left.\left[{ }^{18} \mathrm{~F}\right] \mathrm{FBY}\right)$, a PET tracer with favorable dosimetry profile and pharmacokinetics, was also developed, which shows potential to assay large neutral amino acid transporter type-1 (LAT-1) expression in glioma patients and may provide imaging guidance for further boron neutron capture therapy of gliomas [65]. [ ${ }^{18} \mathrm{~F}$ ]FBQ- $\mathrm{C}_{2}$ was designed by adding two more methylene groups to the side chain of ${ }^{18} \mathrm{~F}$-fluoroboronoglutamine ( $\left.\left[{ }^{18} \mathrm{~F}\right] \mathrm{FBQ}\right) .\left[{ }^{18} \mathrm{~F}\right] \mathrm{FBQ}-\mathrm{C}_{2}$ shows greater in vivo stability than that of ${ }^{18} \mathrm{~F}-(2 \mathrm{~S}, 4 \mathrm{R}) 4$-fluoroglutamine $\left(\left[{ }^{18} \mathrm{~F}\right]\right.$ FGln) and $\left[{ }^{18} \mathrm{~F}\right] \mathrm{FBQ}$, and it can be used to perform [82]. lational Oncology, Vol. 14/1, Zhang X et al. [61, 62], Evaluation of ${ }^{99 \mathrm{~m}} \mathrm{Tc}-\mathrm{CN} 5 \mathrm{DG}$ as a broad-spectrum SPECT probe for tumor imaging, 100,966, Copyright (2021), with permission from Elsevier

Tang's group reported a new amino acid tracer $\mathrm{N}-\left(2-\left[{ }^{18} \mathrm{~F}\right]-\right.$ fluoropropionyl)-L-glutamate ([ $\left.\left.{ }^{18} \mathrm{~F}\right] \mathrm{FPGLU}\right)$ [66], which seems to be a better potential PET tracer than $\left[{ }^{18} \mathrm{~F}\right] \mathrm{FDG}$ for brain glioma imaging with good visualization and ability to assess the tumor activity, and they also confirmed that excitatory amino acid carrier 1 is an important transporter of $\left[{ }^{18} \mathrm{~F}\right] \mathrm{FPGLU}$ in oncologic PET.

\section{Other tumor imaging agents}

Besides the tumor imaging agents mentioned above, other tumor targeting radiotracers for imaging of hypoxia and a variety of tumor receptors have also been extensively explored which including: radiolabeled nitroimidazole derivatives for hypoxia imaging such as $\left[{ }^{64} \mathrm{Cu}\right] \mathrm{Cu}-\mathrm{BMS} 181321$ [67], $\left[{ }^{64} \mathrm{Cu}\right] \mathrm{Cu}-\mathrm{BMS} 2 \mathrm{P} 2$ [68], and $\left[{ }^{18} \mathrm{~F}\right] \mathrm{FDG}-2 \mathrm{NNC} 2 \mathrm{ON}[69] ;{ }^{68} \mathrm{Ga}-$ and $\left[{ }^{18} \mathrm{~F}\right]$ AlF-labeled NOTA-MAL-Cys39-exendin-4 for 
the detection of glucagon-like peptide 1 receptor (GLP-1R)-positive tumor [70, 71]; ${ }^{18} \mathrm{~F}$-labeled ethisterone derivative $\left[{ }^{18} \mathrm{~F}\right] \mathrm{FPTT}$ for imaging of progesterone receptor-positive breast cancer [72]; ${ }^{18} \mathrm{~F}$-labeled isonicotinamide-based radioligands for investigating the glycogen synthase kinase-3 $\beta$ (GSK-3 $\beta$ ) levels [73]; $\left[{ }^{18}\right.$ F]FP-Lys-GE11 for imaging of the epidermal growth factor receptor (EGFR) over expressed tumor [74]; $\left[{ }^{18} \mathrm{~F}\right]-5$-fluoro-N-(2-(Diethylamino)ethyl) picolinamide $\left(\left[{ }^{18} \mathrm{~F}\right] 5-\mathrm{FPN}\right)$ for the detection of metastatic lymph node and metastatic pulmonary lesions of melanoma [75]; [ ${ }^{99 \mathrm{~m}} \mathrm{Tc}$ ]Tc-HYNIC-Polypeptide$\mathrm{PEG}_{11}-\mathrm{Tz}(1,2,4,5$-tetrazine) and cetuximab-TCO for the pretargeted imaging of human colon cancer tumor [76]; $\left[{ }^{68} \mathrm{Ga}\right] \mathrm{Ga}-\mathrm{NOTA}-\mathrm{Nb} 1053$ for visualizing multiple myeloma niduses [19]; and [ $\left.{ }^{99 \mathrm{~m}} \mathrm{Tc}\right] \mathrm{Tc}-\mathrm{HYNIC}-\mathrm{H} 10 \mathrm{~F}$ for imaging of HER2-positive tumors [77].

\section{Imaging agents for other diseases}

Some radiotracers targeting other diseases have also been developed including a purinergic receptor P2X7 antagonist $\left[{ }^{18}\right.$ F]F-PTTP for the detection of inflammation [78], [ $\left.{ }^{99 \mathrm{~m}} \mathrm{Tc}\right] \mathrm{Tc}-\mathrm{GlcNAc}-\mathrm{PEI}$ (N-acetylglucosamine (GlcNAc) conjugated polyethylenimine (PEI)) specifically interacts with desmin and vimentin expressed on activated hepatic stellate cells (HSCs) for assessing liver fibrosis [79], $\left[{ }^{18} \mathrm{~F}\right]$ FPGal based on isotonicamide for the imaging of asialoglycoprotein receptor (ASGPR) related liver disease [80], and $\left[{ }^{68} \mathrm{Ga}\right] \mathrm{Ga}-\mathrm{HZ} 20$ for the quantitative analysis of angiotensin

Table 2 The representative tracers under research and development in China

\begin{tabular}{|c|c|c|c|c|}
\hline Disease & Molecular targets & Radiopharmaceuticals & Stage & Reference \\
\hline \multirow[t]{2}{*}{ Alzheimer's disease } & Amyloid- $\beta$ plaques & {$\left[{ }^{18} \mathrm{~F}\right]$ Florbetazine, $\left[{ }^{18} \mathrm{~F}\right] \mathrm{DRKXH} 1$} & Clinical & Cui [27], Xu [20] \\
\hline & Tau protein & $(R)-\left[{ }^{18} \mathrm{~F}\right] 5 \&(S)-\left[{ }^{18} \mathrm{~F}\right] 16$ & Preclinical & Zhou [33] \\
\hline Brain dysfunction & Sigma-1 receptors & {$\left[{ }^{18} \mathrm{~F}\right] \mathrm{FBFP}$} & Preclinical & Jia [39] \\
\hline Coronary artery disease & & {$\left[{ }^{99 \mathrm{~m}} \mathrm{Tc}\right] \mathrm{Tc}-3 \mathrm{SPboroxime} ;\left[{ }^{18} \mathrm{~F}\right] \mathrm{Fmpp} 2$} & Preclinical & Zhao [40, 41], Zhang [42] \\
\hline \multirow[t]{14}{*}{ Tumor } & PSMA & $\begin{array}{l}\text { ODAP-based ligands, }\left[{ }^{99 \mathrm{~m}} \mathrm{Tc}\right] \mathrm{Tc}-\mathrm{HYNIC}-\mathrm{ALUG} \\
{\left[{ }^{18} \mathrm{~F}\right] 8 \mathrm{c} \text { (with quinoline spacer) }}\end{array}$ & $\begin{array}{l}\text { Preclinical } \\
\text { Clinical }\end{array}$ & $\begin{array}{l}\text { Duan [44], Liu [45] } \\
\text { Zhang [46] }\end{array}$ \\
\hline & Intergrin $\alpha_{v} \beta_{3}$ & $\begin{array}{l}{\left[{ }^{18} \mathrm{~F}\right] \mathrm{F}-\text { Alfatide, }\left[{ }^{99 \mathrm{~m}} \mathrm{Tc}\right] \mathrm{Tc}-3 \mathrm{PRGD} 2} \\
{\left[{ }^{68} \mathrm{Ga}\right] \mathrm{Ga} \text {-cycratide, }\left[{ }^{99 \mathrm{~m}} \mathrm{Tc}\right] \mathrm{Tc}-\mathrm{RWY}} \\
{\left[{ }^{68} \mathrm{Ga}\right] \mathrm{Ga}-\text { NOTA-PEG3- } \beta \text {-Glu-RGD }}\end{array}$ & $\begin{array}{l}\text { Phase III } \\
\text { Clinical } \\
\text { Preclinical }\end{array}$ & $\begin{array}{l}\text { Mi [48], Yu [51] } \\
\text { Feng [49], Gao [52] } \\
\text { Ma [50] }\end{array}$ \\
\hline & PD-1/PD-L1 & $\begin{array}{l}{ }^{99 m} \mathrm{Tc}-\text { labeled anti-PD-L1-single-domain antibody } \\
{\left[{ }^{18} \mathrm{~F}\right] \mathrm{LN},\left[{ }^{124} \mathrm{I}\right] \mathrm{I}-\mathrm{anti}-\mathrm{hPD}-\mathrm{L} 1 \mathrm{Nb6}} \\
{\left[{ }^{64} \mathrm{Cu}\right] \mathrm{Cu}-\mathrm{NOTA}-\mathrm{Nb} 6,\left[{ }^{124} \mathrm{I}\right] \mathrm{I}-\mathrm{JS} 001} \\
{\left[{ }^{68} \mathrm{Ga}\right] \mathrm{Ga}-N O T A-W L 12}\end{array}$ & $\begin{array}{l}\text { Phase I } \\
\text { Preclinical } \\
\text { Preclinical } \\
\text { Clinical }\end{array}$ & $\begin{array}{l}\text { Xing [54] } \\
\text { Miao [55], Huang [56] } \\
\text { Jiang [57], Huang [58] } \\
\text { Yang [59] }\end{array}$ \\
\hline & Glucose & {$\left[{ }^{99 \mathrm{~m}} \mathrm{Tc}\right] \mathrm{Tc}-\mathrm{CN} 7 \mathrm{DG} ;\left[{ }^{99 \mathrm{~m}} \mathrm{Tc}\right] \mathrm{Tc}-\mathrm{CN} 5 \mathrm{DG}$} & Clinical & Gan [60], Zhang[61] \\
\hline & Amino acid & $\begin{array}{l}{\left[{ }^{18} \mathrm{~F}\right] \mathrm{Ala}-\mathrm{BF}_{3},\left[{ }^{18} \mathrm{~F}\right] \mathrm{Gln}-\mathrm{BF}_{3},\left[{ }^{18} \mathrm{~F}\right] \mathrm{FBQ}-\mathrm{C}_{2},\left[{ }^{18} \mathrm{~F}\right]} \\
\text { FPGLU } \\
{\left[{ }^{18} \mathrm{~F}\right] \mathrm{FBY}}\end{array}$ & $\begin{array}{l}\text { Preclinical } \\
\text { Clinical }\end{array}$ & $\begin{array}{l}\text { Liu [63], Li [64], Chen } \\
\text { [82], Tang [66] } \\
\text { Li [65] }\end{array}$ \\
\hline & Hypoxia & $\begin{array}{l}{\left[{ }^{64} \mathrm{Cu}\right] \mathrm{Cu}-\mathrm{BMS} 181321,\left[{ }^{64} \mathrm{Cu}\right] \mathrm{Cu}-\mathrm{BMS} 2 \mathrm{P} 2\left[{ }^{18} \mathrm{~F}\right]} \\
\text { FDG-2NNC2ON }\end{array}$ & Preclinical & $\begin{array}{l}\text { Luo [67], Luo [68] } \\
\text { Yang [69] }\end{array}$ \\
\hline & GLP-1R & $\begin{array}{l}{ }^{68} \mathrm{Ga} \text { and }\left[{ }^{18} \mathrm{~F}\right] \mathrm{AlF}-\mathrm{labeled} \text { NOTA-MAL-Cys39- } \\
\text { exendin-4 }\end{array}$ & Preclinical & $\mathrm{Xu}$ [70], Zhang [71] \\
\hline & Progesterone receptor & {$\left[{ }^{18} \mathrm{~F}\right] \mathrm{FPTT}$} & Preclinical & Gao [72] \\
\hline & GSK-3 $\beta$ & ${ }^{18} \mathrm{~F}$-Labeled isonicotinamide-based radioligands & Preclinical & Zhong [73] \\
\hline & EGFR & {$\left[{ }^{18} \mathrm{~F}\right] \mathrm{FP}-\mathrm{Lys}-\mathrm{GE} 11$} & Preclinical & $\operatorname{Li}[74]$ \\
\hline & Melanin & {$\left[{ }^{18} \mathrm{~F}\right] 5-\mathrm{FPN}$} & Preclinical & Wang [75] \\
\hline & Pretargeting & $\begin{array}{l}\left.{ }^{[99 \mathrm{~m}} \mathrm{Tc}\right] \mathrm{Tc}-\mathrm{HYNIC} \text {-polypeptide-PEG }{ }_{11}-\mathrm{Tz}(1,2,4,5- \\
\text { tetrazine }) \text { and cetuximab-TCO }\end{array}$ & Preclinical & Qiu [76] \\
\hline & CD38 & {$\left[{ }^{68} \mathrm{Ga}\right] \mathrm{Ga}-\mathrm{NOTA}-\mathrm{Nb} 1053$} & Preclinical & Wang [19] \\
\hline & HER2 & {$\left[{ }^{99 \mathrm{~m}} \mathrm{Tc}\right] \mathrm{Tc}-\mathrm{HYNIC}-\mathrm{H} 10 \mathrm{~F}$} & Preclinical & $\mathrm{Wu}[77]$ \\
\hline Inflammation & $\mathrm{P} 2 \mathrm{X} 7$ & {$\left[{ }^{18} \mathrm{~F}\right] \mathrm{F}-\mathrm{PTTP}$} & Preclinical & $\mathrm{Fu}[78]$ \\
\hline Liver fibrosis & Activated HSCs & {$\left[{ }^{99 \mathrm{~m}} \mathrm{Tc}\right] \mathrm{Tc}-\mathrm{GlcNAc}-\mathrm{PEI}$} & Preclinical & Zhang [79] \\
\hline Liver disease & ASGPR & {$\left[{ }^{18} \mathrm{~F}\right] \mathrm{FPGal}$} & Preclinical & Sun $[80]$ \\
\hline Coronavirus & ACE2 & {$\left[{ }^{68} \mathrm{Ga}\right] \mathrm{Ga}-\mathrm{HZ} 20$} & Clinical & Zhu [81] \\
\hline
\end{tabular}

*Preclinical: radiotracers are under stage of animal study; clinical: radiotracers are under clinical research with healthy volunteers or patients Phase I-III: radiotracers are under different stages of clinical trials 
converting enzyme 2 (ACE2) expression in novel coronavirus sensitive organs [81].

The representative tracers mentioned above are summarized in Table 2.

\section{Therapeutic radiopharmaceuticals}

Since $\left[{ }^{177} \mathrm{Lu}\right] \mathrm{Lu}$-DOTA-TATE was successively approved by European Medicines Agency (EMA) and FDA for the treatment of gastroenteropancreatic neuroendocrine tumors (GEP-NETs), and along with the positive results obtained from phase III clinical trial of $\left[{ }^{177} \mathrm{Lu}\right] \mathrm{Lu}$-PSMA-617 developed by Novartis for the treatment of metastatic castrationresistant prostate cancer (mCRPC), ${ }^{177} \mathrm{Lu}$-labeled radiopharmaceuticals has attracted increasing attention in radionuclide therapy.

Zhu's group has carried out the clinical translational researches of $\left[{ }^{177} \mathrm{Lu}\right] \mathrm{Lu}$-DOTA-EB-TATE, a radiolabeled somatostatin analog modified by Evans blue [83]. In addition, the group is also conducting a clinical study of $\left[{ }^{177} \mathrm{Lu}\right]$ Lu-EB-PSMA.

Radiolabeling, kit formulation, and animal biodistribution of $\left[{ }^{177} \mathrm{Lu}\right] \mathrm{Lu}-\mathrm{EDTMP}$ and $\left[{ }^{177} \mathrm{Lu}\right] \mathrm{Lu}-\mathrm{DOTMP}$ have been investigated $[84,85]$. Shanghai Huashan Hospital conducted the first clinical study of ${ }^{177} \mathrm{Lu}$-labeled radiopharmaceuticals in China which is $\left[{ }^{177} \mathrm{Lu}\right] \mathrm{Lu}-\mathrm{EDTMP}$ for the pain palliation of bone metastases [86]. Ma et al. conducted radiolabeling study and preliminary biological evaluation of $\left[{ }^{177} \mathrm{Lu}\right] \mathrm{Lu}-$ Rituximab [87]. Liu's group developed a highly tumor-selective anti-PD-L1 ( $\alpha$ PD-L1) antibody, and subsequent radioimmunotherapy with $\left[{ }^{177} \mathrm{Lu}\right] \mathrm{Lu}-\alpha \mathrm{PD}-\mathrm{L} 1$ antibody showed that this ${ }^{177} \mathrm{Lu}$-labeled antibody could successfully upregulate antitumor immunity in the tumor microenvironment and turn "cold" tumors "hot" for immunotherapy [88]. Liu et al. investigated ${ }^{177} \mathrm{Lu}$-labeled panitumumab and cetuximab (conjugated with DOTA), and the results suggested that both ${ }^{177} \mathrm{Lu}$-labeled antibodies were promising for targeted therapy of EGFR-positive tumors especially for those that are resistant to antibody-based immunotherapy [89].

Alpha particles have high linear energy transfer (LET) and moderate path length, giving them an effective range of less than 10 cell diameters, which means cancer cells can be significantly damaged while causing minimal toxicity to the surrounding healthy cells. This renders targeted alpha therapy significant advantages, and it thus has become the hotspot of nuclear medicine research [90].

Based on homemade ${ }^{211} \mathrm{At}$, several research works on ${ }^{211}$ At-labeled agents have been carried out. Using N-succinimidyl-5-(tributylstannyl)-3-pyridinecarboxylate (SPC) as a bi-functional linker [91], a one-step method was used for the preparation of [ $\left.{ }^{211} \mathrm{At}\right] \mathrm{At}-\mathrm{SPC}-\mathrm{VP} 2$ peptide [92]. The following research suggests that $\left[{ }^{211} \mathrm{At}\right] \mathrm{At}-\mathrm{SPC}-\mathrm{VP} 2$ has good in vivo stability and shows potential for targeted cancer radiotherapy.

First investigation of the possible use of ${ }^{211}$ At-labeled octreotide as a potential alpha-radionuclide therapeutic agent for non-small cell lung cancer cell treatment was reported by Yu's group [93]. [ ${ }^{211} \mathrm{At}$ ]At-SPC-octreotide was prepared by indirect method, and it demonstrates much more lethal effect than the control groups (PBS, octreotide, and free ${ }^{211} \mathrm{At}$ ) and a radiation dose-dependent apoptosis-inducing ability.

\section{Radiopharmaceuticals under commercial clinical development or market approval process}

In recent years, along with the technological advancement in the research and development of radiopharmaceuticals, and also with the introduction of NMPA's policy to encourage new drug creation, a lot of domestic and foreign radiopharmaceutical companies have been stepping up efforts on radiopharmaceuticals registration application in China. A batch of new radiopharmaceuticals have entered either the approval process or the clinical trials or marketing approval stage, and some of these radiopharmaceuticals are expected to be approved and serve the patients clinically in the near future. The current status of radiopharmaceutical application and approval by the NMPA in China is listed in Table 3.

\section{Future perspectives}

In the past 10 years, major progress has been made in the research and development of diagnostic and therapeutic pharmaceuticals for cancer, cardiovascular system and central nervous system diseases, immunotherapy inflammation, and infection. Some radiopharmaceuticals are in the stage of clinical translation or marketing authorization. However, the radiopharmaceuticals currently in clinical application in China are mainly generic drugs, and the gap compared with developed countries is still quite significant, especially in the area of research and development and clinical translation of therapeutic radiopharmaceuticals. Proceeding from the actual situation in China, the important future trends may be including the following aspects: (1) production of medical radionuclides using both reactors and accelerators; (2) development of new targeted radiopharmaceuticals; and (3) improvement of radiopharmaceuticals supervision.

In order to meet the basic requirements of the development of diagnostic and therapeutic radiopharmaceuticals, the production of the most important medical radionuclides such as ${ }^{99} \mathrm{Mo},{ }^{131} \mathrm{I},{ }^{177} \mathrm{Lu}$, and ${ }^{123} \mathrm{I}$ needs to be emphasized in China. In addition, novel theranostic radionuclides pairs and alpha radionuclides such as ${ }^{123 / 124} \mathrm{I},{ }^{64 / 67} \mathrm{Cu},{ }^{44 / 47} \mathrm{Sc}$, 
Table 3 Radiopharmaceuticals under commercial clinical development in China

\begin{tabular}{|c|c|c|c|}
\hline Drug name & Company name & Status & Indications \\
\hline$\left[{ }^{18} \mathrm{~F}\right] \mathrm{F}$-Alfatide injection & Jiangsu Shimeikang Pharmaceutical Co., Ltd & Phase III & Tumor diagnosis \\
\hline $\begin{array}{l}{\left[{ }^{18} \mathrm{~F}\right] \text { Flutemetamol }} \\
\text { injection }\end{array}$ & $\begin{array}{l}\text { General Electric Pharmaceutical (Shanghai) } \\
\text { Co., Ltd }\end{array}$ & Phase I-II & $\begin{array}{l}\text { Diagnosis of Alzheimer's disease related to } \\
\beta \text {-amyloid neuritic plaques }\end{array}$ \\
\hline $\begin{array}{l}{\left[{ }^{18} \mathrm{~F}\right] \mathrm{APN}-1607} \\
\text { injection }\end{array}$ & Suzhou Xinxu Pharmaceutical Co., Ltd & Phase III & $\begin{array}{l}\text { Diagnosis and evaluation of neurodegenerative } \\
\text { diseases including Alzheimer's disease and } \\
\text { cognitive impairment related to Tau protein } \\
\text { pathology }\end{array}$ \\
\hline$\left[{ }^{18} \mathrm{~F}\right]$ Florbetaben injection & Tianjin HTA Isotope Medicine Co., Ltd & Phase III & $\begin{array}{l}\text { Diagnosis of Alzheimer's disease related to } \\
\beta \text {-amyloid neuritic plaques }\end{array}$ \\
\hline \multirow[t]{2}{*}[{}^{18}\mathrm{F}]{$\mathrm{NaF}$ injection } & $\begin{array}{l}\text { Nanjing Jiangyuan AMS Positron Research } \\
\text { and Development Co., Ltd }\end{array}$ & Phase III & $\begin{array}{l}\text { Diagnosis of bone metastasis of malignant } \\
\text { tumor }\end{array}$ \\
\hline & HTA Co., Ltd & Phase III & \\
\hline$\left[{ }^{18} \mathrm{~F}\right]$ Florbetapir injection & $\begin{array}{l}\text { Nanjing Jiangyuan AMS Positron Research } \\
\text { and Development Co., Ltd }\end{array}$ & Phase II & $\begin{array}{l}\text { Diagnosis of Alzheimer's disease related to } \\
\beta \text {-amyloid neuritic plaques }\end{array}$ \\
\hline$\left[{ }^{99 \mathrm{~m}} \mathrm{Tc}\right] \mathrm{Tc}-3 \mathrm{PRGD} 2$ injection & Foshan Ruidiao Pharmaceutical Co., Ltd & Phase III & $\begin{array}{l}\text { Diagnosis of benign and malignant lung tumors } \\
\text { and lung lymph node metastasis }\end{array}$ \\
\hline$\left[{ }^{99 \mathrm{~m}} \mathrm{Tc}\right] \mathrm{Tc}-\mathrm{CNDG}$ injection & Beijing Shihong Drug Development Center & Phase I & Diagnosis of benign and malignant tumors \\
\hline$\left[{ }^{99 \mathrm{~m}} \mathrm{Tc}\right] \mathrm{Tc}-\mathrm{GSA}$ injection & Beijing Shihong Drug Development Center & Phase III & $\begin{array}{l}\text { Diagnose the function and morphology of the } \\
\text { liver }\end{array}$ \\
\hline$\left[{ }^{123}\right.$ I] Ioflupane injection & GE Pharmaceutical (Shanghai) Co., Ltd & Phase III & Diagnosis of Parkinson's syndrome \\
\hline$\left[{ }^{90} \mathrm{Y}\right]$-Glass microspheres & $\begin{array}{l}\text { Fangen (Tianjin) Pharmaceutical Development } \\
\text { Co., Ltd }\end{array}$ & Phase III & Therapy of unresectable primary liver cancer \\
\hline$\left[{ }^{90} \mathrm{Y}\right]$-resin microspheres & Grandpharma (China) Co., Ltd & Phase II & Therapy of inoperable primary liver cancer \\
\hline$\left[{ }^{131} \mathrm{I}\right] \mathrm{MIBG}$ injection & HTA Co., Ltd & Phase III & $\begin{array}{l}\text { Diagnosis of neuroblastoma and pheochromo- } \\
\text { cytoma }\end{array}$ \\
\hline$\left[{ }^{177} \mathrm{Lu}\right] \mathrm{Lu}-\mathrm{DOTA}-\mathrm{TATE}$ injection & $\begin{array}{l}\text { Advanced Accelerator Applications S.A.; } \\
\text { Jingding pharmaceutical research and devel- } \\
\text { opment (Shanghai) Co., Ltd }\end{array}$ & Phase III & Therapy of neuroendocrine tumor \\
\hline$\left[{ }^{188} \mathrm{Re}\right] \mathrm{Re}-\mathrm{HEDP}$ injection & $\begin{array}{l}\text { Yantai Dongcheng Pharmaceutical Group Co., } \\
\text { Ltd }\end{array}$ & Phase II & $\begin{array}{l}\text { Palliation of bone pain caused by bone metas- } \\
\text { tases }\end{array}$ \\
\hline$\left[{ }^{131} \mathrm{I}\right] \mathrm{I}$-Actuximab injection & $\begin{array}{l}\text { Shanghai Haikang Chinese Medicine Technol- } \\
\text { ogy Development Co., Ltd }\end{array}$ & Phase I & Therapy of advanced malignant solid tumor \\
\hline
\end{tabular}

*Data from http://www.cde.org.cn

${ }^{68} \mathrm{Ge} /{ }^{68} \mathrm{Ga},{ }^{89} \mathrm{Zr},{ }^{211} \mathrm{At},{ }^{225} \mathrm{Ac}$, and ${ }^{223} \mathrm{Ra}$ need to be paid more attention.

As an indispensable tool of molecular imaging, the future focus should be on the development of new positron radiopharmaceuticals including central nervous system receptorbinding radiopharmaceuticals with high affinity and selectivity and peptide-based imaging radiopharmaceuticals. The recent major advancements in solid-state detector technology have led to dramatic improvements of the sensitivity and spatial resolution of SPECT cameras with a concomitant sharp shortening of acquisition times. The SPECT imaging is still very active and can efficiently continue to complement PET diagnostic in routine clinical studies. Because of China's large size and uneven development of nuclear medicine, ${ }^{99 \mathrm{~m}} \mathrm{Tc}$ radiopharmaceuticals is expected to remain the mainstream of diagnostic radiopharmaceuticals for a long time, and thus, more new categories of ${ }^{99 \mathrm{~m}} \mathrm{Tc}$ radiopharmaceuticals need to be explored and developed.
The theranostic radiopharmaceutical which is an integral part of nuclear medicine to achieve precision medicine will be a major future trend. The combination of ${ }^{123} \mathrm{I}^{1131} \mathrm{I}$ radiopharmaceuticals already has found a well-recognized clinical application. By comparison, ${ }^{68} \mathrm{Ga} /{ }^{177} \mathrm{Lu},{ }^{64} \mathrm{Cu} /{ }^{67} \mathrm{Cu}$, ${ }^{44} \mathrm{Sc} /{ }^{47} \mathrm{Sc}$, and other radionuclide pairs and combinations, as well as a number of new targets, especially certain "broadspectrum" targets such as FAP and PSMA, have emerged as research focus in recent years. Many antibody based biotargets that have been clinically applied, such as PD-L1, CEA, MUC1, and HER2, also provide multiple options for the development of related radiopharmaceuticals, for example, the use of ${ }^{89} \mathrm{Zr} /{ }^{64} \mathrm{Cu}$-labeled antibodies for radioimmunoimaging, and the use of ${ }^{177} \mathrm{Lu} /{ }^{90} \mathrm{Y} /{ }^{131} \mathrm{I}$-labeled antibodies for radioimmunotherapy.

Furthermore, attention should also be paid to the unique advantages and promising prospects of targeted alpha therapy. The development and clinical application of alpha 
radiopharmaceuticals such as ${ }^{225} \mathrm{Ac}$ - and ${ }^{211} \mathrm{At}$-labeled radiopharmaceuticals should be promoted and advanced.

The past few years have witnessed a great number of revisions and improvements in relevant laws and regulations to better accommodate the characteristics of radiopharmaceuticals. Still, more rules and regulations that are both applicable and feasible need to be introduced, and the evaluation mechanism for radiopharmaceuticals remains to be further improved so as to provide better policy guarantee to the clinical trials and industrialization of new radiopharmaceuticals.

As stated above, the issuing of the Mid-and Long-term Development Plan (2021-2035) for Medical Isotopes will promote the clinical application of radiopharmaceuticals, meanwhile, to advance the research and development of new radiopharmaceuticals. We expect that through all the unremitting efforts put into the area, radiopharmaceuticals will play a crucial role in the improvement and enhancement of the quality of human life and health care in China.

Supplementary Information The online version contains supplementary material available at https://doi.org/10.1007/s00259-021-05615-6.

Acknowledgements The authors express gratitude to Mr. Zhihao Song, Xuhu Huang, Hailong Zhao, Kai Wen, Xiangyu Qin, Weihua Cheng, Chengwei Ma, and Tianwei Luo for the help of literature search, and to Ms. Jinqi Zhou for revising the language of the manuscript.

Author contribution JD conceptualized and designed the study; HYL and YYS performed literature search; JH and HYL performed articles selection and drafted the paper; YYS and JD critically commented the paper; all the authors critically revised the paper and approved the submitted version of the manuscript.

Availability of data and material The manuscript represents valid work, and neither this manuscript nor one with substantially similar content under the same authorship has been published or is being considered for publication elsewhere.

\section{Declarations}

Ethics approval This article does not contain any studies with human participants or animals performed by any of the authors.

Conflict of interest The authors declare no competing interests.

\section{References}

1. Zhang J, Luo Z. The progress of radioisotope technology and application in China. Engineering Sciences. 2008;6(2):19-31. http://www.cnki.com.cn/Article/CJFDTotal-ENSC200802003. htm. Accessed 8 Nov 2021.

2. Liang J, Wu Y, Luo Z. Development of radioisotope preparation technology at CIAE. Atomic Energy Science and Technology. 2020;54, Suppl.:177-84 (in Chinese). http://www.aest.org.cn/CN/ Y2020/V54/Izengkan/177. Accessed 8 Nov 2021.
3. Zhang H, Luo S, Liu G, Zhong Z. Isotope technologies in INPC: state of the art and perspective. Journal of Isotopes. 2011;24, Suppl.(Suppl):116-20 (in Chinese). http://www.tws.org.cn/CN/ Y2011/V24/I增刊/116. Accessed 8 Nov 2021.

4. Jia H, Liu B. Radiopharmaceuticals in China: current status and prospects. Radiochim Acta. 2014;102(1-2):53-67. https://doi.org/ 10.1515/ract-2014-2100.

5. Zhang J, Du J. Preparation of radiopharmaceuticals in china: current status and prospects. Journal of Isotopes. 2019;32(3):178-85 (in Chinese). https://doi.org/10.7538/tws.2019.32.03.0178

6. Chinese Society of Nuclear Medicine. A brief report on the results of the national survey of nuclear medicine in 2020. Chin J Nucl Med Mol Imaging. 2020;40(12):747-9 (in Chinese). http://doi. org/10.3760/cma.j.cn321828-20201109-00403.

7. Xia Z, Luo Z. Review of the evaluation of radiopharmaceuticals. Chin J Nucl Med Mol Imaging. 2006;26(1):49-50 (in Chinese). http://rs.yiigle.com/CN321828200601/162190.htm. Accessed 8 Nov 2021.

8. Liang J, Shen Y, Wu Y, Xiang X, Yu N, Guo S, et al. Development of simulated process for medical fission ${ }^{99}$ Mo production using electroplating $\mathrm{UO}_{2}$ target with low enriched uranium. Journal of Isotopes. 2018;31(3):165-72 (in Chinese). http://www.tws.org.cn/ CN/10.7538/tws.2018.31.03.0165.

9. Luo Z, Wu Y, J L. Methods for production of medical radioisotope ${ }^{99}$ Mo. Journal of Isotopes. 2018;31(3):129-42 (in Chinese). http:// www.tws.org.cn/CN/10.7538/tws.2018.31.03.0129.

10. Huang W, Liang J, Wu Y, Yu N, Xiang X. Investigation on separation of ${ }^{99} \mathrm{Mo}$ from low enriched uranium target by $\mathrm{Al}_{2} \mathrm{O}_{3}$ chromatography. Journal of Isotopes. 2021;34(1):54-60 (in Chinese). http://www.tws.org.cn/CN/10.7538/tws.2021.34.01.0054.

11. Peng S, Yang Y, Xie X, Qian D. Current status and prospects of reactor produced medical radioisotopes in China. Chin Sci Bull. 2020;65(32):3526-37 (in Chinese). https://doi.org/10.1360/ TB-2020-0374.

12. Shen Y, Chen Y, Liang J, Qiao L, Deng X, Li G, et al. Preparation of Ni target for cyclotron-produced ${ }^{64} \mathrm{Cu}$ by electrodeposition. Journal of Isotopes. 2013;26(1):38-41 (in Chinese). http://www. tws.org.cn/CN/10.7538/tws.2013.26.01.0038 ..

13. Chen Y, Liang J, Li G, Deng X, Qiao L, Shen Y, et al. Chemical separation of ${ }^{64} \mathrm{Cu}$ from irradiated $\mathrm{Ni}$ target by anion exchange method. Journal of Isotopes. 2012;25(3):144-8 (in Chinese). http://www.tws.org.cn/CN/10.7538/tws. 2012.25.03.0144. Accessed 8 Nov 2021.

14. Deng X, Zhao Z, Zhang B, Liu Y, Liu S, Li M, et al. Development of ${ }^{124} \mathrm{Xe}$ gas target system for production of high purity ${ }^{123} \mathrm{I}$. Atomic Energy Science and Technology. 2016;50(07):1324-8 (in Chinese). https://www.cnki.com.cn/Article/CJFDTotal-YZJS2 01607028.htm. Accessed 8 Nov 2021.

15. Tang Y, Li S, Yang Y, Chen W, Wei H, Wang G, et al. A simple and convenient method for production of ${ }^{89} \mathrm{Zr}$ with high purity. Appl Radiat Isot. 2016;118:326-30. https://doi.org/10.1016/j. apradiso.2016.09.024.

16. Liu N, Yang Y, Jin J, Lin R, Cao Y, Liao J, et al. Preparation of radioactive isotopes by CS-30 cyclotron and their applications. Journal of Isotopes. 2012;25(3):189-92 (in Chinese). http://www. tws.org.cn/CN/10.7538/tws.2012.25.03.0189.

17. Wang Q, Wang Y, Ding J, Wang C, Zhou X, Gao W, et al. A bioorthogonal system reveals antitumour immune function of pyroptosis. Nature. 2020;579(7799):421-6. https://doi.org/10. 1038/s41586-020-2079-1.

18. Wu Y, Li L, Wang Z, Shi J, Hu Z, Gao S, et al. Imaging and monitoring HER2 expression in breast cancer during trastuzumab therapy with a peptide probe ${ }^{99 \mathrm{~m}} \mathrm{Tc}-\mathrm{HYNIC}-\mathrm{H} 10 \mathrm{~F}$. Eur J Nucl Med Mol Imaging. 2020;47(11):2613-23. https://doi.org/10.1007/ s00259-020-04754-6. 
19. Wang C, Chen Y, Hou YN, Liu Q, Zhang D, Zhao H, et al. ImmunoPET imaging of multiple myeloma with $\left[{ }^{68} \mathrm{Ga}\right] \mathrm{Ga}-\mathrm{NOTA}-\mathrm{Nb} 1053$. Eur J Nucl Med Mol Imaging. 2021;48(9):2749-60. https://doi.org/ 10.1007/s00259-021-05218-1.

20. Xu M, Guo J, Gu J, Zhang L, Liu Z, Ding L, et al. Preclinical and clinical study on $\left[{ }^{18}\right.$ F]DRKXH1: a novel $\beta$-amyloid PET tracer for Alzheimer's disease. Eur J Nucl Med Mol Imaging. 2021. https://doi.org/10.1007/s00259-021-05421-0.

21. Liu T, Liu C, Zhang Z, Zhang N, Guo X, Xia L, et al. ${ }^{64} \mathrm{Cu}-\mathrm{PSMA}-\mathrm{BCH}$ : a new radiotracer for delayed PET imaging of prostate cancer. Eur J Nucl Med Mol Imaging. 2021;48(13):4508-16. https://doi.org/10.1007/ s00259-021-05426-9.

22. Duan X, Cao Z, Zhu H, Liu C, Zhang X, Zhang J, et al. ${ }^{68} \mathrm{Ga}$-labeled ODAP-Urea-based PSMA agents in prostate cancer: first-in-human imaging of an optimized agent. Eur J Nucl Med Mol Imaging. 2021. https://doi.org/10.1007/ s00259-021-05486-x.

23. Ding J, Zhang Y, Wen J, Zhang H, Wang H, Luo Y, et al. Imaging CXCR4 expression in patients with suspected primary hyperaldosteronism. Eur J Nucl Med Mol Imaging. 2020;47(11):2656-65. https://doi.org/10.1007/s00259-020-04722-0.

24. Xie Q, Liu T, Ding J, Zhou N, Meng X, Zhu H, et al. Synthesis, preclinical evaluation, and a pilot clinical imaging study of $\left[{ }^{18} \mathrm{~F}\right] \mathrm{AlF}-\mathrm{NOTA}-J R 11$ for neuroendocrine neoplasms compared with $\left[{ }^{68} \mathrm{Ga}\right] \mathrm{Ga}-D O T A-T A T E$. Eur J Nucl Med Mol Imaging. 2021;48(10):3129-40. https://doi.org/10.1007/ s00259-021-05249-8.

25. You L, Guo Z, Zhang X. Current status and prospects of radiopharmaceuticals for diagnosis. Journal of Isotopes. 2017 30(4):292-306 (in Chinese). http://www.tws.org.cn/CN/Y2017/ V30/I4/292. Accessed 8 Nov 2021.

26. Busche MA, Hyman BT. Synergy between amyloid- $\beta$ and tau in Alzheimer's disease. Nat Neurosci. 2020;23(10):1183-93. https:// doi.org/10.1038/s41593-020-0687-6.

27. Cui M, Zhou K, Shen L, Deng X. Dihydrazone compounds having high affinity to $A \beta$ protein and Tau protein, derivatives thereof and use thereof. China Patent, CN109704988A, 20190503 (in Chinese). https://www.incopat.com/detail/init2?formerQuery= wE2KAomDT2 iaiJrWYUfKOmr4kAd0KKkg\&local=zh. Accessed 8 Nov 2021

28. Cui M, Wang X, Yu P, Zhang J, Li Z, Zhang X, et al. Synthesis and evaluation of novel ${ }^{18} \mathrm{~F}$ labeled 2-pyridinylbenzoxazole and 2-pyridinylbenzothiazole derivatives as ligands for positron emission tomography (PET) imaging of $\beta$-amyloid plaques. J Med Chem. 2012;55(21):9283-96. https://doi.org/10.1021/jm300973k.

29. Song J, Peng X, Li L, Yang F, Zhang X, Zhang J, et al. $\mathrm{Al}{ }^{18} \mathrm{~F}$-NODA benzothiazole derivatives as imaging agents for cerebrovascular amyloid in cerebral amyloid angiopathy. ACS Omega. 2018;3(10):13089-96. https://doi.org/10.1021/acsom ega.8b01120.

30. Yang Y, Wang X, Yang H, Fu H, Zhang J, Zhang X, et al. Synthesis and monkey-PET study of (R)- and (S)- ${ }^{18}$ F-labeled 2-arylbenzoheterocyclic derivatives as amyloid probes with distinctive in vivo kinetics. Mol Pharm. 2016;13(11):3852-63. https://doi. org/10.1021/acs.molpharmaceut.6b00643.

31. Song J, Zhang X, Zhao Y, Yang H, Zhang J, Zhang X, et al. (R)- and (S)- ${ }^{18}$ F-labeled 2-arylbenzofurans with improved pharmacokinetics as $\beta$-amyloid imaging probes. Eur J Med Chem. 2017;134:271-80. https://doi.org/10.1016/j.ejmech.2017.03.073.

32. Li Y, Zhou K, Guo W, Cui M. ${ }^{18}$ F-labeled 2-phenylbenzoheterocycles with chiral dihydroxyl side chains as $\beta$-amyloid imaging probes. Biorg Med Chem. 2021;29: 115884. https://doi.org/10. 1016/j.bmc.2020.115884.

33. Zhou K, Yang F, Li Y, Chen Y, Zhang X, Zhang J, et al. Synthesis and evaluation of fluorine-18 labeled 2-phenylquinoxaline derivatives as potential tau imaging agents. Mol Pharm. 2021;18(3):1176-95. https://doi.org/10.1021/acs.molpharmac eut.0c01078.

34. Banister SD, Manoli M, Kassiou M. The development of radiotracers for imaging sigma $(\sigma)$ receptors in the central nervous system (CNS) using positron emission tomography (PET). J Labelled Compd Radiopharmaceut. 2013;56(3-4):215-24. https:// doi.org/10.1002/jlcr.3010.

35. He Y, Xie F, Ye J, Deuther-Conrad W, Cui B, Wang L, et al. 1-(4$\left[{ }^{18}\right.$ F]Fluorobenzyl)-4-[(tetrahydrofuran-2-yl)methyl]piperazine: a novel suitable radioligand with low lipophilicity for imaging $\sigma 1$ receptors in the brain. J Med Chem. 2017;60(10):4161-72. https:// doi.org/10.1021/acs.jmedchem.6b01723.

36. Ye J, Wang X, Deuther-Conrad W, Zhang J, Li J, Zhang X, et al. Synthesis and evaluation of a ${ }^{18} \mathrm{~F}$-labeled 4-phenylpiperidine4-carbonitrile radioligand for $\sigma 1$ receptor imaging. J Labelled Compd Radiopharmaceut. 2016;59(9):332-9. https://doi.org/10. 1002/jlcr.3408.

37. Xie F, Bergmann R, Kniess T, Deuther-Conrad W, Mamat C, Neuber C, et al. ${ }^{18}$ F-Labeled 1,4-dioxa-8-azaspiro[4.5]decane derivative: synthesis and biological evaluation of a $\sigma 1$ receptor radioligand with low lipophilicity as potent tumor imaging agent. J Med Chem. 2015;58(14):5395-407. https://doi.org/10.1021/acs. jmedchem.5b00593.

38. Tian J, He Y, Deuther-Conrad W, Fu H, Xie F, Zhang Y, et al. Synthesis and evaluation of new 1-oxa-8-azaspiro[4.5]decane derivatives as candidate radioligands for sigma-1 receptors. Biorg Med Chem. 2020;28(14):115560. https://doi.org/10.1016/j.bmc.2020. 115560.

39. Jia H, Cai Z, Holden D, He Y, Lin S-f, Li S, et al. Positron emission tomography imaging evaluation of a novel 18F-labeled sigma-1 Receptor radioligand in cynomolgus monkeys. ACS Chem Neurosci. 2020;11(11):1673-81. https://doi.org/10.1021/ acschemneuro.0c00171.

40. Zhao Z-Q, Liu M, Fang W, Liu S. Sulfonyl-Containing boronate caps for optimization of biological properties of ${ }^{99 \mathrm{~m}} \mathrm{Tc}$ (III) Radiotracers $\left[{ }^{99 \mathrm{~m}} \mathrm{TcCl}(\mathrm{CDO})(\mathrm{CDOH})_{2} \mathrm{~B}-\mathrm{R}\right]\left(\mathrm{CDOH}_{2}=\right.$ Cyclohexanedione Dioxime). J Med Chem. 2018;61(1):319-28. https://doi. org/10.1021/acs.jmedchem.7b01412.

41. Xi X, Wang L, Hsu B, Zhao Z, Liu S, Fang W. ${ }^{99 m}$ Tc-3SPboroxime: a neutral ${ }^{99 \mathrm{~m}} \mathrm{Tc}(\mathrm{III})$ radiotracer with high heart uptake and long myocardial retention. J Nucl Cardiol. 2020. https://doi.org/ 10.1007/s12350-020-02087-3.

42. Mou T, Zhao Z, You L, Li Y, Wang Q, Fang W, et al. Synthesis and evaluation of ${ }^{18} \mathrm{~F}$-labeled pyridaben analogues for myocardial perfusion imaging in mice, rats and chinese mini-swine. Sci Rep. 2016;6(1):33450. https://doi.org/10.1038/srep33450.

43. Emmett L. Changing the goal posts: prostate-specific membrane antigen targeted theranostics in prostate cancer. Semin Oncol Nurs. 2020;36(4): 151052. https://doi.org/10.1016/j.soncn.2020. 151052.

44. Duan X, Liu F, Kwon H, Byun Y, Minn I, Cai X, et al. (S)-3(Carboxyformamido)-2-(3-(carboxymethyl)ureido)propanoic acid as a novel PSMA targeting scaffold for prostate cancer imaging. J Med Chem. 2020;63(7):3563-76. https://doi.org/10.1021/acs. jmedchem.9b02031.

45. Liu C, Zhu Y, Su H, Xu X, Zhang Y, Song S, et al. Preliminary results of targeted prostate-specific membrane antigen imaging in evaluating the efficacy of a novel hormone agent in metastatic castration-resistant prostate cancer. Cancer Med. 2020;9(10):327886. https://doi.org/10.1002/cam4.2964.

46. Zhang X, Wu Y, Zeng Q, Xie T, Yao S, Zhang J, et al. Synthesis, preclinical evaluation, and first-in-human PET study of quinolinecontaining PSMA tracers with decreased renal excretion. J Med Chem. 2021;64(7):4179-95. https://doi.org/10.1021/acs.jmedc hem.1c00117. 
47. Sani S, Messe M, Fuchs Q, Pierrevelcin M, Laquerriere P, EntzWerle N, et al. Biological relevance of RGD-integrin subtypespecific ligands in cancer. ChemBioChem. 2021;22(7):1151-60. https://doi.org/10.1002/cbic.202000626.

48. Mi B, Yu C, Pan D, Yang M, Wan W, Niu G, et al. Pilot prospective evaluation of ${ }^{18} \mathrm{~F}$-alfatide II for detection of skeletal metastases. Theranostics. 2015;5(10):1115-21. https://www.thno.org/ v05p1115.htm. Accesssed 8 Nov 2021.

49. Feng X, Wang Y, Lu D, Xu X, Zhou X, Zhang H, et al. Clinical translation of a ${ }^{68} \mathrm{Ga}$-labeled integrin $\alpha_{v} \beta_{6}$-targeting cyclic radiotracer for PET imaging of pancreatic cancer. J Nucl Med. 2020;61(10)1461-7. https://doi.org/10.2967/jnumed.119.237347.

50. Ma H, Liu S, Zhang Z, Tang G, Yuan G, Zhao J, et al. Preliminary biological evaluation of ${ }^{68} \mathrm{Ga}$-labeled cyclic RGD dimer as an integrin $\alpha_{\mathrm{v}} \beta_{3}$-targeting radiotracer for tumor PET imaging. J Radioanal Nucl Chem. 2019;321(3):857-65. https://doi.org/10. 1007/s10967-019-06654-y.

51. Yu X, Wu Y, Liu H, Gao L, Sun X, Zhang C, et al. Small-animal SPECT/CT of the Progression and recovery of rat liver fibrosis by using an integrin $\alpha_{\mathrm{v}} \beta_{3}$-targeting radiotracer. Radiology. 2015;279(2):502-12. https://doi.org/10.1148/radiol.2015150090.

52. Gao S, Jia B, Feng G, Dong C, Du H, Bai L, et al. First-in-human pilot study of an integrin $\alpha 6$-targeted radiotracer for SPECT imaging of breast cancer. Signal Transduct Target Ther. 2020;5(1):147. https://doi.org/10.1038/s41392-020-00266-9.

53. Gibney GT, Weiner LM, Atkins MB. Predictive biomarkers for checkpoint inhibitor-based immunotherapy. Lancet Oncol. 2016;17(12):e542-51. https://doi.org/10.1016/S1470-2045(16) 30406-5.

54. Xing Y, Chand G, Liu C, Cook GJR, O'Doherty J, Zhao L, et al. Early Phase I study of a ${ }^{99 m}$ Tc-labeled anti-programmed death ligand-1 (PD-L1) single-domain antibody in SPECT/CT assessment of PD-L1 expression in non-small cell lung cancer. J Nucl Med. 2019;60(9):1213-20. https://doi.org/10.2967/jnumed.118. 224170.

55. Miao Y, Lv G, Chen Y, Qiu L, Xie M, Lin J. One-step radiosynthesis and initial evaluation of a small molecule PET tracer for PD-L1 imaging. Bioorg Med Chem Lett. 2020;30(24): 127572. https://doi.org/10.1016/j.bmcl.2020.127572.

56. Huang H, Zhu H, Li G, Xie Q, Yang X, Xu X, et al. Construction of Anti-hPD-L1 HCAb Nb6 and in situ ${ }^{124}$ I labeling for noninvasive detection of PD-L1 expression in human bone sarcoma. Bioconj Chem. 2019;30(10):2614-23. https://doi.org/10.1021/acs. bioconjchem.9b00539.

57. Jiang J, Zhang M, Li G, Liu T, Wan Y, Liu Z, et al. Evaluation of ${ }^{64} \mathrm{Cu}$ radiolabeled anti-hPD-L1 Nb6 for positron emission tomography imaging in lung cancer tumor mice model. Bioorg Med Chem Lett. 2020;30(4): 126915. https://doi.org/10.1016/j.bmcl. 2019.126915.

58. Huang H, Zhu H, Xie Q, Tian X, Yang X, Feng F, et al. Evaluation of ${ }^{124}$ I-JS001 for hPD1 immuno-PET imaging using sarcoma cell homografts in humanized mice. Acta Pharmaceutica Sinica B. 2020;10(7):1321-30. https://doi.org/10.1016/j.apsb.2020.02.004.

59. Zhou X, Jiang J, Yang X, Liu T, Ding J, Nimmagadda S, et al. First-in-human evaluation of a PD-L1-binding peptide radiotracer in non-small cell lung cancer patients with PET. J Nucl Med. 2021:jnumed.121.262045. https://doi.org/10.2967/jnumed.121. 262045.

60. Gan Q, Zhang X, Ruan Q, Fang Sa, Zhang J. ${ }^{99 m}$ Tc-CN7DG: a highly expected SPECT imaging agent of cancer with satisfactory tumor uptake and tumor-to-nontarget ratios. Mol Pharm. 2021;18(3):1356-63. https://doi.org/10.1021/acs.molpharmaceut. $0 \mathrm{c} 01177$.

61. Zhang X, Ruan Q, Jiang Y, Gan Q, Zhang J. Evaluation of ${ }^{99 \mathrm{~m}} \mathrm{Tc}-$ CN5DG as a broad-spectrum SPECT probe for tumor imaging.
Transl Oncol. 2021;14(1): 100966. https://doi.org/10.1016/j.tranon.2020.100966.

62. Zhang X, Ruan Q, Duan X, Gan Q, Song X, Fang S, et al. Novel ${ }^{99 \mathrm{~m}} \mathrm{Tc}$-labeled glucose derivative for single photon emission computed tomography: a promising tumor imaging agent. Mol Pharm. 2018;15(8):3417-24. https://doi.org/10.1021/acs.molpharmaceut. $8 \mathrm{~b} 00415$.

63. Liu H, Han Y, Li J, Qin M, Fu Q, Wang C, et al. ${ }^{18}$ F-alanine derivative serves as an ASCT2 marker for cancer imaging. Mol Pharm. 2018;15(3):947-54. https://doi.org/10.1021/acs.molph armaceut.7b00884.

64. Li C, Liu H, Duan D, Zhou Z, Liu Z. Preclinical study of an ${ }^{18} \mathrm{~F}$-labeled glutamine derivative for cancer imaging. Nucl Med Biol. 2018;64-65:34-40. https://doi.org/10.1016/j.nucmedbio. 2018.06.007.

65. Li Z, Kong Z, Chen J, Li J, Li N, Yang Z, et al. ${ }^{18}$ F-Boramino acid PET/CT in healthy volunteers and glioma patients. Eur J Nucl Med Mol Imaging. 2021;48:3113-21. https://doi.org/10.1007/ s00259-021-05212-7.

66. Sun A, Liu S, Tang X, Pan Q, Zhang Z, Ma H, et al. N- $\left(2-{ }^{18}\right.$ Ffluoropropionyl)-1-glutamate as a potential oncology tracer for PET imaging of glioma. Appl Radiat Isot. 2021;168: 109530. https://doi.org/10.1016/j.apradiso.2020.109530.

67. Luo Z, Zhu H, Lin X, Hong Y, Xiao S, Zhang Q, et al. Radiolabelling and micro-PET study of ${ }^{64} \mathrm{Cu}$ Labelled PnAO-1-(2nitroimidazole) for hypoxia imaging. Chemical Journal of Chinese Universities. 2015;36(1):87-92 (in Chinese). https://doi.org/10. 7503/cjcu20140438.

68. Luo Z, Zhu H, Lin X, Chu T, Luo R, Wang Y, et al. Synthesis and radiolabeling of ${ }^{64} \mathrm{Cu}$-labeled 2-nitroimidazole derivative ${ }^{64} \mathrm{Cu}-\mathrm{BMS} 2 \mathrm{P} 2$ for hypoxia imaging. Bioorg Med Chem Lett. 2016;26(5):1397-400. https://doi.org/10.1016/j.bmcl.2016.01. 077.

69. Yang X, Wang F, Zhu H, Yang Z, Chu T. Synthesis and bioevaluation of novel $\left[{ }^{18} \mathrm{~F}\right] \mathrm{FDG}$-conjugated 2-nitroimidazole derivatives for tumor hypoxia imaging. Mol Pharm. 2019;16(5):2118-28. https://doi.org/10.1021/acs.molpharmaceut.9b00075.

70. Xu Q, Zhu C, Xu Y, Pan D, Liu P, Yang R, et al. Preliminary evaluation of $\left[{ }^{18} \mathrm{~F}\right]$ AlF-NOTA-MAL-Cys39-exendin-4 in insulinoma with PET. J Drug Targeting. 2015;23(9):813-20. https://doi.org/ 10.3109/1061186X.2015.1020808.

71. Zhang $\mathrm{P}, \mathrm{Zhao} \mathrm{Z}$, Zhang L, Wu W, Xu Y, Pan D, et al. $\left[{ }^{68} \mathrm{Ga}\right]$ Ga-NOTA-MAL-Cys39-exendin-4, a potential GLP-1R targeted PET tracer for the detection of insulinoma. Nucl Med Biol. 2019;74-75:19-24. https://doi.org/10.1016/j.nucmedbio.2019. 08.002 .

72. Gao F, Peng C, Zhuang R, Guo Z, Liu H, Huang L, et al. ${ }^{18} \mathrm{~F}$-labeled ethisterone derivative for progesterone receptor targeted PET imaging of breast cancer. Nucl Med Biol. 2019;7273:62-9. https://doi.org/10.1016/j.nucmedbio.2019.07.001.

73. Zhong Y, Yang S, Cui J, Wang J, Li L, Chen Y, et al. Novel ${ }^{18} \mathrm{~F}$-labeled isonicotinamide-based radioligands for positron emission tomography imaging of glycogen synthase kinase-3 $\beta$. Mol Pharm. 2021;18(3):1277-84. https://doi.org/10.1021/acs.molph armaceut.0c01133.

74. Li X, Hu K, Liu W, Wei Y, Sha R, Long Y, et al. Synthesis and evaluation of $\left[{ }^{18} \mathrm{~F}\right] \mathrm{FP}-\mathrm{Lys}-\mathrm{GE} 11$ as a new radiolabeled peptide probe for epidermal growth factor receptor (EGFR) imaging. Nucl Med Biol. 2020;90-91:84-92. https://doi.org/10.1016/j.nucme dbio.2020.10.004.

75. Wang Y, Li M, Zhang Y, Zhang F, Liu C, Song Y, et al. Detection of melanoma metastases with PET-comparison of ${ }^{18} \mathrm{~F}-5-\mathrm{FPN}$ with 18F-FDG. Nucl Med Biol. 2017;50:33-8. https://doi.org/ 10.1016/j.nucmedbio.2017.03.005.

76. Qiu L, Tan H, Lin Q, Si Z, Mao W, Wang T, et al. A pretargeted imaging strategy for immune checkpoint ligand Pd-L1 expression 
in tumor based on bioorthogonal Diels-Alder click chemistry. Mol Imag Biol. 2020;22(4):842-53. https://doi.org/10.1007/ s11307-019-01441-3.

77. Wu Y, Li L, Dong C, Wang F. Small-animal SPECT/CT imaging with $99 \mathrm{mTc}-\mathrm{HYNIC}-\mathrm{H} 10 \mathrm{~F}$ detects HER 2 expression in mice bearing human breast cancers. J Nucl Med. 2016;57(supplement 2):1162. https://jnm.snmjournals.org/content/57/supplement_2/ 1162. Accessed 8 Nov 2021.

78. Fu Z, Lin Q, Hu B, Zhang Y, Chen W, Zhu J, et al. P2X7 PET Radioligand ${ }^{18}$ F-PTTP for differentiation of lung tumor from inflammation. J Nucl Med. 2019;60(7):930-6. https://doi.org/10. 2967/jnumed.118.222547.

79. Zhang D, Zhuang R, Guo Z, Gao M, Huang L, You L, et al. Desmin- and vimentin-mediated hepatic stellate cell-targeting radiotracer ${ }^{99 \mathrm{~m}} \mathrm{Tc}-\mathrm{GlcN} A \mathrm{c}-\mathrm{PEI}$ for liver fibrosis imaging with SPECT. Theranostics. 2018;8(5):1340-9. https://www.thno.org/ v08p1340.htm. Accessed 8 Nov 2021.

80. Sun P, Zhu Y, Han Y, Hu K, Huang S, Wang M, et al. Radiosynthesis and biological evaluation of an fluorine-18 labeled galactose derivative $\left[{ }^{18} \mathrm{~F}\right] \mathrm{FPGal}$ for imaging the hepatic asialoglycoprotein receptor. Bioorg Med Chem Lett. 2020;30(12): 127187. https://doi.org/10.1016/j.bmcl.2020.127187.

81. Zhu H, Zhang H, Zhou N, Ding J, Jiang J, Liu T, et al. Molecular PET/CT profiling of ACE2 expression in vivo: implications for infection and outcome from SARS-CoV-2. Adv Sci. 2021;8(16):2100965. https://doi.org/10.1002/advs.202100965.

82. Chen J, Li C, Hong H, Liu H, Wang C, Xu M, et al. Side chain optimization remarkably enhances the in vivo stability of ${ }^{18} \mathrm{~F}$-labeled glutamine for tumor imaging. Mol Pharm. 2019;16(12):5035-41. https://doi.org/10.1021/acs.molpharmac eut.9b00891.

83. Liu Q, Zang J, Sui H, Ren J, Guo H, Wang H, et al. Peptide receptor radionuclide therapy of late-stage neuroendocrine tumor patients with multiple cycles of ${ }^{177}$ Lu-DOTA-EB-TATE. J Nucl Med. 2021:62(3):386-92. https://doi.org/10.2967/jnumed.120. 248658.

84. Deng X, Li H, Ye Z, Guo H, Li F, Luo Z. Radiolabeling and biodistribution of ${ }^{177} \mathrm{Lu}$-EDTMP and ${ }^{177} \mathrm{Lu}$-DOTMP. Journal of Isotopes. 2009;22(2):71-5 (in Chinese). http://www.tws.org.cn/ CN/volumn/volumn_1150.shtml\#1. Accessed 8 Nov 2021.

85. Li H, Liang J, Xiang X, Deng X, Zheng D, Luo H. Biodistribution and imaging study on ${ }^{177} \mathrm{Lu}$-EDTMP prepared by kit method. Journal of Isotopes. 2010;23(2):65-70 (in Chinese). http://www.
tws.org.cn/CN/10.7538/tws.2010.23.02.0065. Accessed 8 Nov 2021.

86. Yuan J, Liu C, Liu X, Wang Y, Kuai D, Zhang G, et al. Efficacy and safety of ${ }^{177} \mathrm{Lu}$-EDTMP in bone metastatic pain palliation in breast cancer and hormone refractory prostate cancer: a phase ii study. Clin Nucl Med. 2013;38(2):88-92. https://doi.org/10.1097/ RLU.0b013e318279bf4d.

87. Ma X, Zhang J, Li H, Liang J, Yang Y, Yang C. Preparation and preliminary biological evaluation of ${ }^{177} \mathrm{Lu}$ labelled rituximab. Journal of Isotopes. 2014;27(2):98-103 (in Chinese). http://www. tws.org.cn/CN/Y2014/V27/I2/98. Accessed 8 Nov 2021.

88. Ren J, Xu M, Chen J, Ding J, Wang P, Huo L, et al. PET imaging facilitates antibody screening for synergistic radioimmunotherapy with a ${ }^{177} \mathrm{Lu}$-labeled $\alpha$ PD-L1 antibody. Theranostics. 2021;11(1):304-15. https://doi.org/10.7150/thno.45540.

89. Liu Z, Ma T, Liu H, Jin Z, Sun X, Zhao H, et al. ${ }^{177}$ Lu-labeled antibodies for EGFR-targeted SPECT/CT Imaging and radioimmunotherapy in a preclinical head and neck carcinoma model. Mol Pharm. 2014;11(3):800-7. https://doi.org/10.1021/mp400 5047.

90. Targeted alpha therapy working g. targeted alpha therapy, an emerging class of cancer agents: a review. JAMA Oncology. 2018;4(12):1765-72. https://doi.org/10.1001/jamaoncol.2018. 4044.

91. Liu N, Yang Y, Zan L, Liao J, Jin J. Astatine-211 labeling of insulin: synthesis and preliminary evaluation in vivo and in vitro. J Radioanal Nucl Chem. 2007;272(1):85-90. https://doi.org/10. 1007/s10967-006-6781-8.

92. Liu W, Ma H, Tang Y, Chen Q, Peng S, Yang J, et al. One-step labelling of a novel small-molecule peptide with astatine-211: preliminary evaluation in vitro and in vivo. J Radioanal Nucl Chem. 2018;316(2):451-6. https://doi.org/10.1007/s10967-018-5780-x.

93. Zhao B, Qin S, Chai L, Lu G, Yang Y, Cai H, et al. Evaluation of astatine-211-labeled octreotide as a potential radiotherapeutic agent for NSCLC treatment. Biorg Med Chem. 2018;26(5):108691. https://doi.org/10.1016/j.bmc.2018.01.023.

Publisher's note Springer Nature remains neutral with regard to jurisdictional claims in published maps and institutional affiliations. 